\title{
Szútrák a hosszú élethez Amoghavajra fordításában
}

\author{
A Fugen Enmei szútra kutatásának margójára
}

A Taishō shinshū daizōkyō 大正新脩大蔵経 (a későbbiekben csak Taishōzō) kínai Tripițaka ezoterikus buddhista szövegeket tartalmazó 20. kötetében ${ }^{1}$ található öt szútra, amelyeket egy csoportba lehet sorolni: a fő téma mindegyikben az élet meghosszabbítása, avagy a Gyémántélethossz elérése az érző lények/élőlények (j. shujō 衆生) számára. Bár a szövegek alapmotívuma ugyanaz, a szútráknál mégis felfedezhetünk kisebb-nagyobb eltéréseket, akár a szereplőkben vagy a helyszínekben is. A fordító a buddhista kánonokban található megnevezések alapján egy és ugyanazon személy, Amoghavajra (j. Fukū 不空, 705-774), ${ }^{2}$ akiben a 8. századi Tang 唐 Kína egyik legfontosabb ezoterikus buddhista szerzetesének a személyét tisztelhetjük. A jelen tanulmányban vizsgált szútrák és az azokban foglalt ezoterikus tanok a 8-9. század folyamán, japán szerzetesek által kerültek át a szigetországba, ahol a későbbiekben sokkal nagyobb jelentőségre tettek szert. A doktori diszszertációm témájaként szolgáló Fugen Enmei bosatsuval 普賢延命菩薩

Taishō shinshū daizōkyō 大正新脩大蔵経, 20. kötet, 575-580.

2 Több neve, megnevezése is volt: Fukū 不空, Fukū Kongō 不空金剛, Chizō 智蔵. A shingon irányzat 6. pátriárkája. Észak-Indiában született (vagy Sri Lankán, akkori Ceylon), ahonnan 14 évesen Jáva szigetére utazott, ahol Vajrabodhival (j. Kongōchi 金剛智, 671-741) találkozott, és tanítványának állt. 720-ban érkezett először Kínába mesterével, akinek az ezoterikus írások fordításában segédkezett. A mestere halála (741) után Indiába és valószínúleg Sri Lankára utazott, majd 746-ban tért vissza Kínába. Haláláig ott fordította az ezoterikus írásokat, terjesztette az ezoterikus buddhista tanokat. Három kínai császár támogatását is elnyerte élete folyamán, akik tevékenységét megannyi titulussal honorálták. (A két indiai mesterról és életrajzaikról bővebben lásd Chou 1945 és Orlando 1981.) 
(sz. Samantabhadrayū $)^{3}$ kapcsolatos kutatásomhoz, és különösen a bodhisattva által jelképezett tanítás megértéséhez elkerülhetetlen ezeknek a szövegeknek a tanulmányozása, amelyek közül egy kimondottan ennek a bodhisattvának a szútrája. ${ }^{4}$ A másik négy szöveg fókuszában a címekben is szereplő gyémánt (j. kongō 金剛, sz. vajra) - élethossz (j.jumyō 寿命, sz. āyus) áll. Az utóbbi négy szútra rövid elemzését fogom most bemutatni, felderítve, hogy mikor és kik által kerültek Japánba. A történetük bemutatása után pedig külön kiemelem a szútrákban szereplő fóbb motívumokat, felhívva a figyelmet olyan elemekre, amelyek alapján igazoltnak vélhetjük Kūkai 空海 besorolását, miszerint a két alapvető szöveg a Kongōchō kyō 金剛頂経 (Gyémánt-orom szútra, sz. Vajraśekhara sūtra vagy Sarvatathāgatatattvasamigraha sūtra, a továbbiakban STTS) csoportjába tartozik. ${ }^{5}$ A 9. század elején írt munkájában, a Sangakurokuként 三学録 ismertté vált Shingonshū shogaku kyō-ritsu-ron mokurokuban 真言宗所学経律論目録 (A shingon irányzatban tanult szútrák, monasztikus szabályok [sz. vinaya] és értekezések [sz. abhidharma] katalógusa) ugyanis a shingon tanítványok számára fontos szútrák között sorolja fel a jelen tanulmányhoz kapcsolódó két szöveget. ${ }^{6}$

3 „Az életet meghosszabbitó Samantabhadra.” A japán ezoterikus shingon és tendai irányzatokban megtalálható bodhisattva. Doktori disszertációmban az ő ábrázolásának forrásaival és a fennmaradt múvek ikonográfiai változásaival foglalkozom. A bodhisattva szanszkrit megnevezése egy rövid magyarázatot igényel. Habár ez idáig általában a Vajramoghasamayasattva szanszkrit névvel illették (lásd Sawa 1970, vagy a British Museum honlapján az ottani Fugen Enmei-ábrázolásoknál is ez a megnevezés szerepel), azonban ezzel a névvel az Anyaméhvilág-mandala (j. Taizōkai mandara 胎蔵界曼茶羅) Egyetemes bölcsesség szekciójában (j. Henchiin 遍智院) megtalálható húszkarú Daianraku fukū kongō sanmai bosatsut 大安楽 不空金剛三昧菩薩 (,Nagy Öröm és Béke Gyémánt Nem-üres Igaz Samaya bodhisattva”) tartjuk számon. Az általam használt Samantabhadrayū a Fugen Enmei átírása szanszkritra, vagyis Samantabhadra (Fugen 普賢) és ayus (jumyō 寿命, vagyis élethossz). A Fugen Enmei bosatsuhoz köthetô kutatás alapproblémáiról lásd Kiss 2014: 67-92.

4 Bussetsu issai nyoraishin kōmyō kaji Fugen bosatsu enmei kongō saishō darani kyō 仏説一 切如来心光明加持普賢菩隡延命金剛最勝陀羅尼経 (A Buddha által hirdetett, a minden buddha tudatának fényével felhatalmazott Samantabhadrayū leggyőzelmesebb Vajra dhāraṇi szútrája). T 1136, 20. köt. 579-580.

5 A listában szereplő két szöveg megnevezése: 金剛壽命陀羅尼經一卷 és 金剛壽命念誦 法經一卷. URL:http://base1.nijl.ac.jp/iview/Frame.jsp?DB_ID=G0003917KTM\&C_CODE=XSE1-00103 (4-5. lap).

6 Kūkai STTS-hagyományával foglalkozik részletesen Dale Allan Todaro, aki 1985-ös PhD disszertációjában is felsorolja a Sangakurokuban ismertetett múveket, bár az általam most itt tárgyalt szútrákkal nem foglalkozik részletesen, lásd Todaro 1985: 60-61. 


\section{A szútrák}

Jelen tanulmány címében már olvasható, hogy ezúttal csak azokkal a szútrákkal fogok foglalkozni, amelyeket a Tang-dinasztia korabeli Kína (618-907) egyik legfontosabb śramanája, ${ }^{7}$ Amoghavajra fordított, és fómotívumuk a gyémánt élethossz. Ezt azért tartom célszerúnek kiemelni, mivel ezeken kívül vannak még olyan szútrák a Taishōzō 20. és 21. köteteiben, amelyek középpontjában szintén a hosszú élet áll, de most ezek vizsgálatához csak abban az esetben folyamodom, amennyiben a négy szútra elemzése vagy megértése megköveteli azt.

Hatsuzaki Shōjun 初崎正純, ${ }^{8}$ az ezoterikus buddhista tanokkal behatóan foglalkozó professzor, az 1960-as években készített tanulmányában tizenkét olyan (kínai és tibeti nyelven fennmaradt) szútrát gyújt össze, amely kapcsolódik a jani-tam, vagyis a hosszú élet dhāraṇī kultuszához. ${ }^{10} \mathrm{~A}$ tanulmányban a szerző a 4. századtól datálható szövegeket három csoportra osztja, aszerint, hogy hol zajlik a szövegben megnevezett Buddha igehirdetése:

7 Śramaṇa, szanszkrit szó, jelentése „kereső, kutató, aki aszketikus gyakorlatokat végez.” Vándorló (akár kolduló) aszkéta, szerzetes megnevezése.

8 Hatsuzaki Shōjun 初崎正純, az ezoterikus buddhizmus egyik szakértője, 1966 és 1969 között a Kiotó prefektúrában található Shuchiin Egyetem 種智院大学 óraadó professzora volt. A karrierjéról sajnos egyéb információk nem állnak rendelkezésre, de számos tanulmánya jelent meg az Indogaku bukkyōgaku kenkyū 印度学仏教学哳究 (Indiai és buddhista tanulmányok) címú folyóiratban, mind az ezoterikus buddhizmus témakörében.

9 Dhāran̄ī, szanszkrit szó, alapjelentése „,fenntartani” vagy „megtartani.” Az ezoterikus buddhizmusban a dhāraṇī (vagy a mantra) jelentése a mai napig egy kevéssé megértett, de annál inkább vitatott téma. Jelen álláspont szerint két jelentése, avagy funkciója van a dhāraṇīknak: egyrészt a korábbi szövegekben az emlékezetet hivatott szolgálni, egy-egy írásnak, a tanoknak a memorizálásában segített; másfelől pedig a későbbi ezoterikus szövegekben egyértelmúen varázsigeként szolgálnak, a buddhákhoz és egyéb buddhista istenségekhez intézve, mintegy imaként vagy fohászként is fel lehet fogni ôket. Általában véve a második használati módjuk elterjedtebb, angolul is leginkább a spell vagy incantation szavakkal hivatkoznak a dhāraṇīkra.

10 Hatsuzaki 1966: 225-229 (japán nyelven) vagy Hatsuzaki 1968: 937-942 (angol nyelven). A tanulmányok végén megjegyzik, hogy ezek állami pénzen készülttek a Mikkyō ni okeru enmeihō no seiritsu ni kan suru kenkyū 密教における延命法の成立に関する研究 (Az ezoterikus buddhizmusban található élethosszabbító-szertartás keletkezésével kapcsolatos kutatás) keretében, amely azonban több mint valószínú, hogy félbemaradt, mivel ilyen címen azóta sem jelent meg sem tanulmánykötet, sem monografikus könyv stb. 
a Pippala-fa ${ }^{11}$ alatt, a Gangesz partján, ${ }^{12}$ vagy a Sumeru-hegy ${ }^{13}$ tetején..$^{14} \mathrm{~A}$ három csoport a következő:

1. A Pippala-fa alatti igehirdetések:

- Az erényes tanitások és célszerü eszközök dhāraṇi szútrája (j. Bussetsu zenbō hōben darani kyō 仏説善法方便陀羅尼 経) $)^{15}$

- A gyémánt titok jó módszereinek dhāraṇi szútrája (j. Kongō himitsu zenmon darani kyō 金剛秘密善門陀羅尼経 $)^{16}$

- A gyémánt titok jó módszereinek dhārañi szútrája (j. Kongō himitsu zenmon darani kyō 金剛秘密善門陀羅尼経, másik verzió 異本) $)^{17}$

- Az élet védelme tanítás kapujának varázsige szútrája (j. Gomyō hōmon jinshu kyō 護命法門神呪経) ${ }^{18}$

11 A pippala-fa másik nevén bodhi-fa, amely alatt Siddhārta Gautama, más néven Sākyamuni, a Történeti Buddha (j. Shakamuni 釈迦牟尼) elérte a megvilágosodást.

12 A szövegekben gyakorta a Gangesz-folyó partján tart igehirdetést a Történeti Buddha. Ugyanakkor metaforákban vagy összehasonlításokban is nem egyszer hivatkozik a folyóra, például, amikor a Gangesz medrében található homokszemek sokaságával fejezi ki, hogy valami megszámlálhatatlanul sok.

13 Sumeru-hegy (j. Shumisen 須弥山) vagy Meru-hegy. A buddhista kozmológiában a középső világ-hegy, amely homokóra alakú, és körben víz veszi köruil. A hegy tetején lakozik Śakra (j. Taishakuten 帝釈天) harminckét istenséggel, a hegy felénél pedig a négy égtáj irányában a Négy Mennyei Uralkodó (j. Shitennō 四天王).

14 Hatsuzaki 1966: 226.

15 A Keleti Jin-dinasztia 東晉 korszakában (i. sz. 317-420) fordították, fordítója ismeretlen. T 1137, 20. köt. 580-581.

16 Fordítója ismeretlen. T 1138, 20. köt. 581-582. Két szöveg maradt fenn, lásd a következő lábjegyzet.

17 Fordítója ismeretlen. T 1138, 20. köt. 583-584.

18 Fordítója Bodhiruci (Bodairushi 菩提流支, ?-?), észak-indiai születésú buddhista szerzetes, szútrafordító. 508-ban érkezett meg Luoyang 洛陽 (j. Rakuyō) városába, ahol a Yongningsi 永 寧寺 (j. Eineiji) templomban fordított szanszkrit szútrákat kínai nyelvre. Ezek között a szútrák és szövegek között megtaláljuk a Vajra bölcsesség szútrát (j. Kongō hannya kyō 金剛般若経 vagy Kongo hannya haramitsu kyō 金剛般若波羅蜜経, sz. Vajracchedikā-prajñ̄āpāramitā sūtra), vagy a Vasubandhu (j. Seshin 世親) által írt Végtelen élet szútra (j. Muryōju kyō 無量 寿経, sz. Sukhāvat̄̄-vyūha sūtra) magyarázatokkal ellátott szövegét is. Összesen 127 szöveget tulajdonítanak neki. T 1139, 20. köt. 584-587. 
- A Buddha által hirdetett, a hosszú élet csodálatos kapujának dhāraṇi szútrája (j. Bussetsu enju myōmon darani kyō 仏説 延寿妙門陀羅尼経 $)^{19}$

- Ārya sumukha nāma dhārañĭ $\bar{l}^{20}$

2. A Gangesz-folyó partján történó igehirdetések:

- A tathāgaták ${ }^{21}$ gyülésének dhāraṇi szútrája (j. Shobutsu jūe darani kyo 諸仏集会陀羅尼経 $)^{22}$

- A Buddha által hirdetett, minden buddha Vajra-élethossz. dhāraṇi szútrája (j. Bussetsu issai nyorai kongō jumyō darani kyō 亿説一切如来金剛寿命陀羅尼経 $)^{23}$

- A Buddha által hirdetett, a minden buddha tudatának fényével felruházott Samantabhadrayū legkiválóbb gyémánt-dhārañi szútrája (j. Bussetsu issai nyorai-shin kōmyō kaji Fugen bosatsu enmei kongō saishō darani kyō 仏説一 切如来心光明加持普賢菩薩延命金剛最勝陀羅尼経 $)^{24}$

19 Fordítója Dharmabhadra (j. Hōken 法賢), indiai származású buddhista szerzetes, aki a Song-kori Kínában (960-1279) tevékenykedett 980-tól haláláig, 1000-ig vagy 1001-ig. Kérdéses azonban, hogy ki is volt ô, ugyanis ezt a később felvett nevet két különböző személynek szokták tulajdonítani: egyrészt Devaśāntikának (j. Tensokusai,k. Tianxizai 天息災), egy kashmiri szerzetesnek, másrészt Dharmadevának (j. Hōten, k. Fatian 法天), egy Nālandāból származó szerzetesnek. Tudniillik mindketten új nevet kaptak a kínai Taizong császártól (j. Taisō 太宗, ur. 976-997), méghozzá egy évtizedben (az első 987-ben, a második 982-ben), amely név, úgy néz ki, egy és ugyanaz volt. A legtöbb katalógusban a későbbi kínai megnevezést adják meg (k. Faxian vagy Fa-hsien, Fa-sien alakokban), amiból nem lehetne egyértelmúen eldönteni a fordító kérdését, ugyanakkor a Nanjō katalógusban és a Taishōzō leírásában is 1001 van megadva a fordítás évének, tehát ez egyelőre arra enged következtetni, hogy Dharmadeva lehetett a fordító. T 1140, 20. köt. 587-589.

20 Tibeti nyelven fennmaradt dhāraṇi . Peking No. 0540, rgyud, na, 252a4-257a6 (11. köt. 165.).

${ }^{21}$ Tathāgata (j. nyorai 如来), páli és szanszkrit eredetú szó, jelentése: ,az, aki elnyerte az ok és okozat abszolút útját (j. shinnyo 真如, sz. bhūtatathatā), vagyis elérte a tökéletes végső bölcsességet (megvilágosodást).” A Buddha egyik legmagasabb rangja.

22 Fordítója Devaprajñā (j. Daiun Hannya 提雲般若), indiai származású buddhista szerzetes, aki a Tang-kori Kínában tevékenykedett 692 körül. T 1346, 21. köt. 858-859.

23 Fordítója Amoghavajra. T 1135, 20. köt. 578.

24 Fordítója Amoghavajra. T 1136, 20. köt. 579-580. 
- A korai halál kiküszöbölésének dhāraṇī szútrája (j. Sokujo chūyo darani kyō 息除中夭陀羅尼経 $)^{25}$

- Ārya sarva buddhāngavati nāma dhāraṇī ${ }^{26}$

3. A Sumeru-hegyen történő igehirdetések:

- A gyémánt-élethossz dhārañi megfelelö recitálásának (olvasásának?) szertartása (j. Kongō jumyō darani nenjuhō 金剛 寿命陀羅尼念誦法 $)^{27}$

- A gyémánt-élethossz dhāraṇi szútra szertartása (j. Kongō jumyō darani kyōhō 金剛寿命陀羅尼経法 $)^{28}$

- A gyémánt-élethossz dhāraṇi szútra (j. Kongō jumyō darani $k y \bar{o}$ 金剛寿命陀羅尼経 $)^{29}$

A megnevezésük és tartalmuk alapján a jelen tanulmányban vizsgált négy szútra pedig a következő: ${ }^{30}$

- A gyémánt-élethossz dhārañi megfelelö recitálásának szertartása (a késóbbiekben röviden csak nenjuhō szöveg)

- A gyémánt-élethossz dhārañi szútra szertartása

- A gyémánt-élethossz dhārañi szútra

- A Buddha által hirdetett, minden buddha Vajra-élethossz. dhāraṇi szútrája (a késóbbiekben röviden csak issai szöveg)

A fent említett beosztás szerint a most vizsgált szútrák közül az első három szövegben a Sumeru-hegyen, míg a negyedikben a Gangesz partján történik az igehirdetés. Érdemes tehát ezek szerint két alcsoportra osztani a szútrákat,

25 Fordítója Dānapāla (j. Sego 施護), indiai származású buddhista szerzetes, aki a Song-kori Kínában tevékenykedett 980-tól. T 1347, 21. köt. 860.

26 Tibeti nyelven fennmaradt dhāraṇi . Peking No. 0150, rgyud, na, 19a3-20b6 (6. köt. 157).

27 Fordítója Amoghavajra. T 1133, 20. köt. 575-576.

28 Fordítója Amoghavajra. T 1134A, 20. köt. 576-577.

29 Fordítója Amoghavajra. T 1134B, 577-578.

30 Az ötödik a csoportban a Fugen Enmei szútra (lásd 4. j.). 
mivel az első alcsoportba tartozó (Sumeru-hegy) írások tartalmilag is jobban összefüggnek, ugyanis a három szöveg eleje szinte szóról szóra megegyezik, egészen a gyémánt-élethossz mantra utáni részig, ahonnan már eltérések mutatkoznak a tartalomban. Első ránézésre a Kongō jumyō darani kyō 金剛 寿命陀羅尼経 túnhetne az alap szútrának, azonban látni fogjuk, hogy egyáltalán nem ez a helyzet. A csoportban szerepló másik két szöveg egy-egy szertartást ír le, így talán érthető, hogy a mantra után ezekben a szertartások konkrét leírását találjuk. ${ }^{31}$

Az általános tartalmi pontok összehasonlítását továbbgondolva, a központi buddha alakja sem ugyanaz az írásokban. Az előzőekhez hasonló módon az első három szútránál Birushana buddha 毘盧遮那仏 (sz. Vairocana) szavait hallgatják a jelen lévő tathāgaták, míg a negyedikben a Négy menynyei uralkodó (j. Shitennō 四天王, sz. Lokapāla) esküszik fel valószínúleg Shakamuni 釈迦牟尼 (sz. Sākyamuni) buddha ${ }^{32}$ előtt, hogy segíteni fognak azokon az élólényeken, akik húségesen gyakorolnak és recitálják a mantrát, illetve olvassák a szútrát.

A négy szútra közös pontja, hogy mindegyikben olyan gyakorlatokat, mantrákat vagy dhāraṇīkat olvashatunk, amelyek elvégzése, recitálása által ugyanannak a célnak az elérése tárul fel előttünk: a Gyémánt-élethossz elnyerése, vagyis az élethossz növekedése és az idő előtti halál elkerülése.

\section{A szútrák megjelenése Kínában}

A szövegek története meglehetósen homályos. A rendelkezésre álló adatok alapján mindössze megközelítólegesen nyilatkozhatunk arról, hogy mikor és hogyan érkezhettek meg a szútrák Kínába. Egészen a 20. századig, pontosabban a Taishōzō összeállításáig a négy szöveg közül csak kettő van említve

31 Ezek a leírások újfent csak egy pontig egyeznek meg. A meditációs utasítások még nagyon hasonlóak, de a következő mantra utáni szertartás-leírás már eltér.

32 A tökéletes bizonyosság csak azért nincs meg, mert a buddha nincsen megnevezve a szútrákban, hanem csak egyszerúen a Buddha (j. butsu 仗/佛) szóval van jelölve, amit viszont a Történeti Buddhára, Shakamunira szoktak használni. 
a fontosabb kínai buddhista kánonokban: a nenjuhō (T 1133) és az issai szútra (T 1135).

Származásukat tekintve az tûnik a legvalószínúbbnek, hogy Vajrabodhi (j. Kongōchi 金剛智) és Amoghavajra által kerültek Kínába, akik 720-ban érkeztek meg a kínai fővárosba, ahol egészen az előbbi 741-ben bekövetkezett haláláig tartózkodtak. ${ }^{33}$ Ahogy a legtöbb kínaira fordított indiai szövegnek, ennek a kettőnek sem maradt fenn a (feltehetően) szanszkrit nyelvú eredetije. ${ }^{34}$ Ugyanígy csak ez a két szöveg szerepel abban az 1883-ban kiadott, Nanjō Bunyū által összeállított katalógusban is, amely az egyike a kínai kánon első angol nyelvú ismertetőinek. ${ }^{35}$ Itt az első szöveget (No. 1391) az egyéb indiai szútrákhoz ${ }^{36}$ a másodikat (No. 960) pedig a 10-14. század folyamán a kánonba került mahāyāna vagy hinayāna szövegek közé sorolták. ${ }^{37}$ Az issai szútránál pedig egy olyan megjegyzést is olvashatunk, amely szerint ez a szútra igazából a fentebb is felsorolt Shobutsu jūe darani kyō (No. 495 Nanjōnál) rövidebb verziója, ${ }^{38}$ ahogy Chigyoku 智旭 (k. Zhixu, 1599-1655 $)^{39}$ felhívta rá a figyelmet a 17 . században. ${ }^{40}$ A kapcsolat tagadhatatlan a szövegeket olvasva, azonban mégis kérdéses, hogy ugyanazon szövegnek a két kínai fordításáról beszélhetünk-e. Az utóbbit ugyanis 691 körül ültette át kínaira Devaprajñā (j. Daiun Hannya 提雲般若, ?-?), ${ }^{41}$ aki Khotanból származó szerzetes volt, ahogyan a kínai források több helyen feltüntetik a szútra melletti megjegyzésekben. ${ }^{42}$ Ennél a szövegnél azonban fennmaradt

\footnotetext{
Az életrajzokhoz lásd Chou 1945 és Orlando 1981.

Nanjō 1883.

Nanjō 1883.

Nanjō 1883: 310: „Miscellaneous Works - Indian Miscellaneous Works”.

37 Nanjō 1883: 213: „Sūtra-pitaka - Sūtras of the Mahāyāna and Hinayāna, admitted into the Canon during the later (or Northern) and Southern Sun (A. D. 960-1127 and 1127-1280) and Yuen (A. D. 1280-1368) dynasties".

38 Nanjō 1883: 115.

39 1599-1655, kínai buddhista szerzetes.

40 Nanjō 1883: 213. Nanjō Chigyoku 1654-ben befejezett Etsuzō chiritsu 閲蔵知律 címú múvét idézi bizonyos szútráknál, ahogy az issai szútránál is.

41 Khotani szerzetes, akinek kínai tevékenységéről 689 és 691 között tudunk.

42 A Zoku kokin yakkyō zukiben 續古今譯經圖記 (T 2152), a Daishū kantei shukyō mokuro$k u$ ban 大周刊定衆經目録 (T 2153), a Kaigen shakkyo rokuban 開元釋教録 (T 2154), a Kaigen shakkyō roku ryakushutsuban 開元釋教録略出 (T 2155) és a Teigen shintei shakkyō mokurokuban 貞元新定釋教目録 (T 2157).
} 
egy tibeti eredeti is, míg az issai szövegnél nem (ahogy a Nanjō katalógusban olvashatjuk). ${ }^{43}$ A Taishōzōban ez a szöveg a 21. kötetben (T 1346) szerepel egy másikkal, A korai halál kiküszöbölésének dhāran̄i szútrájával 息除中天 陀羅尼経 (T 1347) együtt, amely szintén ennek lehet egy másik fordítása. ${ }^{44}$

Elsőként a 730-ban a kínai buddhista szerzetes, Chishō 智昇 (k. Zhisheng, ? - ?) által összeállított Kaigen shakkyō roku 開元釈教録 (k. Kaiyuan shijiao $l u)^{45}$ listájában jelenik meg a nenjuhō szöveg címe. ${ }^{46}$ Bár a szövegeket, amelyek között a nenjuho szöveg is fel van sorolva (noha nem ,hō 法," hanem ,kyō 経,” vagyis szútra megnevezéssel), Amoghavajra új fordításainak tartja az író, ${ }^{47}$ nem kizárható, hogy a fiatal (730-ban még csak 25-26 éves) szerzetes a mestere, Vajrabodhi segítségével készíthette el a fordításokat, akivel 720-ban együtt érkezett a kínai fóvárosba. ${ }^{48}$

771-ben Amoghavajra listát készített az addig lefordított szövegekrôl az akkori kínai császár, Taishū 代宗 (k. Daizong, ur. 762-779) ${ }^{49}$ születésnapjának alkalmából. A lista Amoghavajra egyik tanítványa, Enshō 円照 (k. Yuanzhao, 719-800 ${ }^{50}$ feljegyzésében maradt fenn. ${ }^{51}$ Ebben a listában már mindkét szöveg szerepel, ${ }^{52}$ bár itt egy rövid kitérőt kell tennem a szövegek

43 Nanjō 1883: 115.

44 A T 1346-os szöveg már a gyémánt élethossz szútra előtt megjelent Japánban: feljegyzés van arról, hogy 738-ban (Tenpyō 9) a Tōdaiji templomban lemásolták: 寫㑒 諸佛集會羅尼經 一卷. (Nara jidai komonjo furu tekisuto dētabēsu 奈良時代古文書フルテキストデータベ 一ス). URL: https://clioimg.hi.u-tokyo.ac.jp/viewer/view/idata/850/8500/05/0007/0062?m=a $11 \& s=0060 \& n=20(62$.

45 T 2154, 55. köt. Tang-kori, kínaira fordított buddhista szövegek összefoglaló katalógusa. Öszszesen 20 kötetből áll. Röviden csak Kaigen rokunak 開元録 hívják. Az összeállítást Chishō 智昇 Kaigen 18. évében, vagyis 730-ban fejezte be, innen ered a megnevezés is. Hasonló katalógusokat a Keleti Jin-dinasztia idejétől fogva készítettek Kínában, amelyek főleg a Sui- 隋 és a Tang-koban bővülttek látványos mértékben. Mindezen katalógusok közül is kiemelkedik a Kaigen roku a felsorolt 5048 kötetével.

46 T 2154, 55. köt. 700a15: 金剛壽命念誦經一卷 三紙.

47 T 2154, 55. köt. 699c16: 大唐不空三藏新譯衆經論及念誦儀軌法等.

48 Lásd Orlando 1981.

49 Az ezoterikus buddhista tanok és Amoghavajra egyik legnagyobb pártolója volt. Az ő uralkodása alatt kapta meg az indiai szerzetes rangjainak nagy részét.

50 Kínai buddhista szerzetes. A Tang-kori kínai fővárosban, Chang'anban lévő Saimyōji (Ximingsi) 西明寺 templomban tanult.

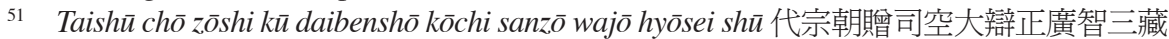
和上表制集, T 2120, 52. köt.

52 T 2120,52. köt. 839b18: 金剛壽命陀羅尼經一卷 és 839c16: 金剛壽命念誦法一卷. 
címére vonatkozóan, ugyanis minden jel arra mutat, hogy amit a 8. században (és talán késóbb is) a Kongō jumyō darani kyōként jelölnek, az nem a T 1134B szútra, hanem a T 1135, vagyis igazából a Bussetsu issai nyorai kongō jumyō darani kyō szútra lesz. Ennek alátámasztására a következő négy pontra hívnám fel a figyelmet:

1. a nenjuhō mellett ez az a szöveg, amely a legtöbb és legrégebbi kánonokban is szerepel; 53

2. szinte az összesben a mesterével együtt nevezik meg Amoghavajrát mint fordítót $;^{54}$

3. már a 8. századi kínai katalógusokban is megjegyzik, hogy igazából az issai szútrát értik ez alatt a név alatt:;5

53 A kínai és koreai kánonok, amelyekben szerepel mindkét szöveg:

- Bōzan sekkyō 房山石経 (k. Fangshan shijing)

- Sūtei daizōkyō 崇寧大蔵経 (k. Chongning dazangjing)

- Biru daizōkyō 毘盧大蔵経 (k. Pilu dazangjing)

- Enkaku daizōkyō 円覚大蔵経 (k. Yuanjie dazangjing)

- Chōjo kinzō 趙城金蔵 (k.Zhaocheng jinzang)

- Shifukuzō 資福蔵 (k.Zifu zang)

- Sekisahan daizōkyō 磧砂版大蔵経 (k. Qishaban dazangjing)

- Kōrai daizōkyō 高麗大蔵経 (Tripitaka Koreana, a koreai kánon, amelyen a Taishōzō is alapszik)

- Futeizō 普寧蔵 (k.Puning zang)

- Shigen roku 至元録 (k. Zhiyuan lu)

- Kōbu nanzōo 洪武南藏 (k. Hongwu nanzang)

- Eiraku nanzō 永楽南蔵 ( $k$. Yongle nanzang).

- Eiraku hokuzō 永楽北蔵 ( $k$. Yongle beizang)

- Kakō daizōkyō 嘉興大蔵経 (k. Jiaxing dazangjing)

- Kenryūzō 乾隆蔵 (k. Qianlong zang).

54 Az előző lábjegyzetben felsorolt kánonok közül mindössze a Bōzan sekkyōban, a Kōrai daizōokyōban és a Shigen rokuban van csak Amoghavajra megnevezve a mestere nélkül. (A Sūtei daizōkyōban, az Enkaku daizōkyōban, a Chōjō kinzōban, a Shifukuzōban, a Futeizōban és az Eiraku nanzōban pedig egyáltalán nincs említés a fordítóról.)

55 Például az Enshō által összeállított Daitō teigen zoku kaigen shakkyō roku 大唐貞元続開元 釈教録 (T 2156), amelyet 795-ben, illetve a Teigen shintei shakkyo mokuroku 貞元新定釈 教目録 (T 2157) is, amelyet halálának évében, 800-ban fejezett be a szerzetes. 
4. a 9. században a japán szerzetes, Annen összefoglaló katalógusában is hasonló megjegyzést olvashatunk..$^{56}$

Arra a kérdésre azonban, hogy milyen úton juthattak a szövegek Kínába, a kutatás jelenlegi állása szerint nem lehet biztos választ adni, mindössze találgatni tudunk abból, amit Vajrabodhi vagy Amoghavajra életrajzában olvashatunk. Az egyetlen támpontunk a gyémánt élethossz mantra lehet, amely - amellett, hogy az egyik alapvető ezoterikus szútrából, a STTS-ből származik - különféle formákban fennmaradt többek között Dunhuangban (j. Tonkō 敦煌), például egy talizmánon, amelyet ma a British Múzeumban óriznek (erról bővebben lásd a tanulmány végén a mantrákkal foglalkozó bekezdéseket). ${ }^{57}$

\section{A szútrák megjelenése Japánban}

A japán források azt bizonyítják, hogy (valószínúleg) az issai szútra már a Nara-korban, vagyis valamikor a 8. század folyamán megérkezett Japánba, azonban egyéb szövegekről ekkor még nincs említés. A szútra másolásának legkorábbi feljegyzése 747-ból (Tenpyō 19) maradt fenn, amely szerint a Tōdaiji 東大寺 templomban készült egy másolat egy Kongō jumyō darani kyōról. ${ }^{58} \mathrm{~A}$ feljegyzést egy Heiei 本栄 nevú szerzetes készítette, aki ebben

56 A kínai katalógusokban a következő szerepel: 經内題云一切如來金剛壽命陀羅尼經 (T 2156, 55. köt. 0767a19, T 2157, 55. köt. 879b23, 931b08, és 1031c07). Annen összesító katalógusában a megjegyzés: 内云一切如來金剛壽命陀羅尼經不空譯貞元新入目録私云前 件金剛智及不空智丽本今見行世而此録中以爲一本者非也. Ó is megjegyzi, hogy a Teigen-kori új katalógusig Vajrabodhi és Amoghavajra közös munkájának tekintették, de ő most a saját katalógusában csak Amoghavajrát jelöli meg fordítónak (T 2176, 55. köt. 1121b14-15).

57 Lásd Hidas 2014.

58 奉請 金綱(岡I)壽命經一卷. A feljegyzés a Shōsōin monjo 正倉院文書, vagyis a Tōdaiji templom szútramásoló csoportjának az iratai között maradt fenn. (Nara jidai komonjo furu tekisuto dètabēsu 奈良時代古文書フルテキストデータベース [A Nara-kori régi iratok teljes szöveges adatbázisa]). URL: https://clioimg.hi.u-tokyo.ac.jp/viewer/view/idata/850/8500/05/0009/0342? $\mathrm{m}=$ all \&s=0342.) 
az időben a nevezett templomban tartózkodott.$^{59}$ Ez arra enged következtetni, hogy ekkorra már ennek a szútrának is megvolt a kínai fordítása. 603tól kezdve mentek japán küldöttségek a Tang Kínába (j. kentōshi 遣唐使), amelyeknek köszönhetően számos japán szerzetes jutott el Kína különböző részeire, és vissza már nemcsak ők, de velük együtt kínai szerzetesek is egész sokan érkeztek Japánba. Ha azt nézzük, hogy 730-ban még nem említik ezt a szútrát Kínában, 747-ben viszont már Japánban másolják, az arra enged következtetni, hogy magát a szútrát valamikor 730 és 735 között fordíthatták le kínaira, ugyanis 747 előtt 735-ben és 736-ban érkeztek utoljára hivatalos hajók Japánba. Ebben az esetben két buddhista szerzetes jöhet szóba, aki magával vihette a szöveget: Fushō 普照 ${ }^{60}$ vagy Genbō 玄防. ${ }^{61}$ Előbbi 736-os hazatérte után abban a Tōdaiji templomban helyezkedett el, ahol később az említett szútrát is lemásolták. Genbō 734-ben érkezett vissza Japánba különféle ábrázolásokkal és körülbelül 5000 kötetnyi buddhista szöveggel (fóképp szútrákkal és abhidharma irodalommal) ${ }^{62}$

A Nara-korban ezen kívül találunk még egy-két hivatkozást: 757-ben (Tenpyō hōji 1) ismét arról tudósítanak minket, hogy lemásolták ezt a szútrát. ${ }^{63}$ Sőt, ugyanebből az évből egy olyan feljegyzés is fennmaradt, amely szerint a már említett ún. „előzményével,” a Shobutsu jūe darani kyōval

59 Heiei (? - ?) életéről keveset tudunk. A Tōdaiji templom két Nara-kori szerzeteséről, Anganról és Heieiről ír Maki Nobuyuki 1994-ben (Maki 1994: 22-47). A tanulmányában az író nem tudhatott erről a feljegyzésról, mivel Heiei Tōdaiji templombeli pályafutásának kezdetét pár hónappal későbbre teszi, mint a mi forrásunk.

60 Japán buddhista szerzetes a Nara-korban (?-?).

61 Japán buddhista szerzetes (?-746), aki 718 és 734 között tartózkodott a Tang Kínában (Abe 1999: 151-152). Genbō életrajzát lásd Genkō shakusho 元亨釈書, Dainihon bukkyō zensho 62. köt.

62 Abe 1999: 151. A Shoku nihongi 続日本紀, az egyik első japán írásos emlék tájékoztat erról minket egy 746-os bejegyzésben, ami Genbō halálakor készült: ,天本十八年六月已亥。 僧玄防死。玄防俗姓阿刀氏。霊亀二年、入唐学問。唐天子、尊防。准三品、令着 紫袈乷。天平七年、随大使多治比真人広成還帰。齎経論五千余巻及諸仏像来。” Kokushi taikei 国史大系 2, 266. (URL: http://dl.ndl.go.jp/info:ndljp/pid/991092.)

63 奉寫金剛壽命陀羅尼経千卷. Shōsōin monjo 正倉院文書. (Nara jidai komonjo furu tekisuto dètabēsu 奈良時代古文書フルテキストデータベース [A Nara-kori régi iratok teljes szöveges adatbázisa.] URL: https://clioimg.hi.u-tokyo.ac.jp/viewer/view/idata/850/8500/05/0 003/0612? $\mathrm{m}=\mathrm{all} \& \mathrm{~s}=0594 \& \mathrm{n}=20$ ). 
együtt másolták a szútrát. ${ }^{64}$ Majd 780-ban a Saidaiji 西大寺 templom egyik leltárában tünik fel ismét, az ,egyéb szövegek” között említik. ${ }^{65}$

A szútra azonban csak a 9. századba, a Heian-korba lépve kezdi meg igazi „karrierjét.” A híres ezoterikus buddhista szerzetesek közül többnél is megtaláljuk az issai szútra vagy a nenjuhō címét a hazaimportált buddhista kincsek listájában. Kūkai-jal 空海 ${ }^{66}$ (774-835) kezdve, aki 806-ban tért haza a szövegekkel, a 9. századi shingon és tendai szerzetesek is érdeklődést mutattak a könyvek iránt, amit fennmaradt feljegyzésekből (j. $k i$ 記) és leltárokból (j. mokuroku 目録) tudunk. Közülük is a leghíresebb az a nyolc szerzetes, aki a shingon és tendai irányzatokból (j. nittō hakka 入唐八家) a Heian-kor első felében járt Kínában, és megannyi szöveggel és ábrázolással, szertartási eszközzel tért haza. ${ }^{67}$ Ekkor látjuk először megjelenni az issai szöveg majdnem teljes megnevezését: először Ennin 円仁 (794-864), ${ }^{68}$ majd Enchin 円珍 (814-891), ${ }^{69}$ és végül

64 金剛壽命陀羅尼經六百廿五卷 $(. .$.$) 諸仏集會陀羅尼經四百卷 Shōsōin monjo 正倉院文$ 書. (Nara jidai komonjo furu tekisuto dētabēsu 奈良時代古文書フルテキストデータベー ス [A Nara-kori régi iratok teljes szöveges adatbázisa.] URL: https://clioimg.hi.u-tokyo.ac.jp/ viewer/view/idata/850/8500/05/0004/0242?m=all\&s=0242).

65 西大寺資財流記帳上 - 雑経四百九十八巻 - 金剛壽命陀羅尼経九十巻, Saidaiji monjo 西大寺文書 (A Saidaiji templom iratai, feljegyzései), 101. doboz, 5. szöveg. (Nihon komonjo yunion katarogu dètabēsu 日本古文書ユニオンカタログデータベース [A régi japán iratok egységes katalógus-adatbázisa].)

${ }^{66}$ Japán buddhista szerzetes, a shingon irányzat meghonosítója Japánban. Más néven Kōbō daishi 弘法大師. 804 és 806 között járt Kínában, ahol Huikuónál (j. Keika 恵果), Amoghavajra közvetlen tanítványánál kapott beavatást az ezoterikus tanokba. A shingon irányzat 8. pátriárkája. Kūkairól bővebben lásd Kiyota 1978, Abe 1999.

67 A nyolc szerzetes: Saichō 最澄 (767-822, tendai), Kūkai 空海 (774-835, shingon), Jōgyō 常 暁 (?-867), Engyō 円行 (799-852), Eun 恵運 (798-869), Ennin 円仁 (794-864), Enchin 円珍 (814-891) és Shūei 宗㪍 (809-884). A nyolc szerzetesről bővebben lásd Takami 1978-1980.

68 Japán tendai buddhista szerzetes. Más néven Jikaku daishi 慈覚大師, a tendai iskola harmadik fő szerzetese (j. zasu 座主). A fennmaradt feljegyzések alapján ő volt az első szerzetes, aki Fugen Enmei bosatsu ábrázolását Japánba vitte. Ennin naplójában találjuk azt a feljegyzést, miszerint a Wutai-hegyen a Fugen csarnokban látott egy érdekes Fugen-ábrázolást, amely három elefánton ült (Reischauer 1955b: 255). Róla és kínai utazásáról bővebben lásd Reischauer 1955a, 1955b.

69 Japán tendai szerzetes. Más néven Chishō daishi 智証大師, a tendai iskola ötödik fő szerzetese (zasu) 873-tól. A Miidera 三井寺 (más néven Onjōji 園城寺), és ezzel a jimon irányzat (j. jimon ha 寺門派) megalapítója, amely hosszú évszázadokon keresztül rivalizált a sanmon hának 山門派 nevezett iskolával, ami az Enryakuji 延暦寺 tendai főtemplom tanait jelentette, és amelyet Ennin és tanítványai nevével fémjeleztek. (A szerzetesről bővebben lásd a Mikkyō taikei 密教大系 (1995) 6. kötetében található tanulmányokat; illetve Ono Katsutoshi 1982-83. Nittō guhō gyōreki no kenkyū: Chishō daishi Enchin hen 入唐求法行歴の哳究: 智證大師円珍篇 [Chishō daishi Enchin Nittō guhō gyōrekijének tanulmányozása].) 
Annen 安然 (841-889? $)^{70}$ katalógusában is felbukkan a hosszú élethez kapcsolódó szövegek között, ahol az addig Japánba vitt szövegeket gyújti össze a szerzetes. ${ }^{71}$

A japán kutatók által preferált tiszta és zavaros ezoterikus tanok szerinti csoportosítás egy példájával találkozunk a négy most tárgyalt szöveg és a Fugen Enmei szútra esetében is. Annak ellenére, hogy a szútra már a Nara-kor közepén megjelent Japánban, egyelőre semmilyen bizonyítékát nem látni, hogy azt használták volna bármilyen módon. ${ }^{72} \mathrm{Az}$ első olyan feljegyzés ugyanis, amelyben már a használatának (ebben az esetben felolvasásának) egyik alkalmáról olvashatunk, 852-ből származik, Enchin tollából. ${ }^{73}$ Ebben arról tudósit, hogy a császári palotában (j. gosho 御所) a szútrát napi ötször olvasták fel, vagyis összes 1950-szer, illetve rögtön mellette van az is, hogy a hosszú élet mantrát napi háromszázszor recitálták, összesen 119 ezer alkalommal. ${ }^{74}$ Még egy bizonyítékát láthatjuk tehát annak, hogy Kūkainak, Saichōnak 最澄 és a 9. századi japán shingon és tendai szerzeteseknek köszönhetô az ezoterikus buddhista tanok rendszerezése, a különféle szertartások bevezetése a császári udvarba.

A 10. századtól kezdve fog még inkább elterjedni a gyémánt élethossz szövegek használata, amikortól már az Enmei vagy Fugen Enmei szertartások alatt is általánossá vált a szútra felolvasása. ${ }^{75}$ Egy 916-os feljegyzésben

70 Japán tendai buddhista szerzetes. Őt tartják a tendai iskola ezoterikus irányzata megalapítójának, annak, aki először integrálta az ezoterikus tanokat.

71 Ennin: Nittō shingū shōkyō mokuroku 入唐新求聖教目錄 (T 2167, 55. köt. 1097c27); Enchin: Seiryūji guhō mokuroku 青龍寺求法目録 (T 2171, 55. köt. 1096a05) és Nihon biku Enchin nittō guhō mokuroku 日本比丘圓珍入唐求法目録 (T 2172, 55. köt. 1097b29); Annen: Sho ajari shingon mikkyō burui sōroku 諸阿闍梨真言密教部類綜録 (T 2176, 55. köt. 1121b11).

72 Erre vonatkozólag egyelőre semmilyen feljegyzést nem lehet találni az eddig megtekintett forrásgyújteményekben.

73 Chishō daishi zensh $\bar{u}$ 智証大師全集 1917-18, 1297-1298.

74 Chishō daishi zensh $\bar{u}$ 智証大師全集 1917-18, 1297-1298.

75 Az Enmei és a Fugen Enmei szertartásokról, amelyeket a nevükben is jelzett élethosszabbítás okán tartottak a 10. századtól kezdve, minden nagyobb shingon és tendai szertartásgyújteményben olvashatunk. Habár maguk az írók is elismerik, hogy a kettő megkülönböztetése igen homályos, a Fugen Enmei szertartás az, amelyet az alapnak tartanak. A szertartás alkalmával egy ācārya (j. ajari 阿闍梨), avagy magas rangú tanító szerzetes és általában húsz segédszerzetes tevékenykedik, akár hét napon keresztül, több oltáron (a főoltáron, a homa oltáron és egyéb hindu eredetú istenségek oltárain) bemutatva különféle rítusokat. Ezekről több 
találjuk az első említést arra vonatkozóan, hogy ünnepi alkalomból másolják a szútrát. ${ }^{76} \mathrm{Az}$ ünnepi alkalom Uda visszavonult császár 宇多上皇 50 . születésnapja volt, amelyre arany írásjegyekkel másolták le a Kongō jumyō darani kyōt. ${ }^{77}$ Ebből és a fent említett 852-es alkalomból is kiderül, hogy egészen a kezdetektôl fogva szoros volt a kapcsolat a császári család és az élethosszabbító szövegek, mantrák és szertartások között.

\section{A fordító kérdése}

Ma már minden szakirodalmi szövegben, szótárban, katalógusban stb. Amoghavajra van megnevezve az összes szöveg mellett mint fordító. Amint láthattuk fentebb, a nenjuhō szövegnél már a kezdetektől fogva Amoghavajrát tartották a fordítónak, ennek ellenére a későbbi másolatokban fennmaradt kánonokban így is két helyen van mester és tanítvány neve egymás mellett említve fordítóként. ${ }^{78}$ Nem mehetünk el szó nélkül azon tény mellett sem,

hosszabb beszámoló fennmaradt, többek között két Kamakura-kori szertartásgyújteményben, a shingon szerzetes Kakuzen 覚禅 által összeállított Kakuzenshōban 覚禅鈔 vagy a tendai Shōchō 承澄 által szerkesztett Asabashōban 阿娑縛抄 (Taishōzzo zuzō 大正蔵図像, 5. és 9. kötet). Nyolc megtartott szertartásnak a részletes leírását pedig a Monyōkiban 門葉記 találjuk, ami a kiotói Shōrenin 青蓮院 tendai templom feljegyzéseit tartalmazza (Taishōzō zuzō 大正 蔵図像, 11. kötet).

76 Habár a feljegyzésben csak Jumyō kyōként 壽命經 szerepel, más forrásokból tudjuk, hogy a Kongō jumyō (darani) kyōt rövidítették ilyen módon. Megtudjuk azt is, hogy Atsuyoshi herceg 敦慶親王 (888-930), Uda császár 宇多天皇 negyedik fia másolta le, a Ninnaji templomban tartott szertartásra. (Dai nihon shiryo sōgō dètabēsu 大日本史料総合データベース [A japán történeti források nagy összefogó adatbázisa.] URL: https://clioimg.hi.u-tokyo.ac.jp/ viewer/view/idata/850/8500/02/0104/0870?m=all\&s=0870.)

77 Hasonló arany írásjegyes másolat maradt fenn a hiroshimai Itsukushima szentély múzeumában, amelyet 1178-ban készített Taira no Chikamune 本親宗 (1144-1199), ahogyan az utószóban (j. okugaki 奥書) lejegyezték. Ez a szútra is igazából az issai szöveg lesz, ahogy a hiroshimai fontos kulturális értékekként (j. bunkazai 文化財) számon tartott múvek internetes oldalán található képen is kiolvasható a címe: URL: http://www.pref.hiroshima.lg.jp/site/bunkazai/bunkazai-data-102050040.html.

78 Az egyik a Bōzan sekkyō 房山石経, amit a Sui-dinasztia 隋 idején kezdtek el összeírni, és a fordító megnevezése a következőképpen alakul: 大興善寺三蔵沙門金剛智 不空奉詔譯. A másik a Kakō daizōkyō 嘉興大蔵経, amihez a nyomóblokkokkal 1677-re készültek el, a fordító megnevezése pedig így hangzik: 唐金剛智共不空譯. A buddhista kánonokról bővebben lásd Jiang - Chia 2015. (A kánonok rövid bemutatása: 1ásd függelék, 311-320). 
hogy a négy szövegból kettőnél nincs kiírva a fordító neve, csak bizonyos rangok vannak jelölve. A rangok alapján azonban egyértelmúvé válik a fordító kérdése, amelyek megfejtéséhez segítséget nyújtanak a kínai ezoterikus buddhizmussal vagy a tiszteleti címekkel foglalkozó szakirodalmi múvek. ${ }^{79}$ A szövegek sorrendje szerint a négy megnevezés a következő:

- Kaifu gidō sanji tokushinshiki kōrokei sukoku kōshokuyū sanzenko shishi sō shikū shi daikanshōgō daikōchi Daikōzenji sanzō shamon Fukū hōshō yaku 開府儀同三司 特進試鴻臚卿肅國公食邑三千戸賜紫贈司空湓大鑒正 號大廣智大興善寺三藏沙門不空奉詔譯 (T 1133)

- Tokushinshiki kōrokei daibenshōchi sanzō hōshō yaku 特進 試鴻臚卿大辨正廣智三藏奉詔譯 (T 1134A)

- Tokushinshiki kōrokei daibenshōchi sanzō hōshō yaku 特進 試鴻臚卿大辨正大廣智三藏奉詔譯 (T 1134B)

- Kaifu gidō sanji tokushinshiki kōrokei sukoku kōshokuyū sanzenko shishi sō shikū shi daikanshōgō daikōchi Daikōzenji sanzō shamon Fukū hōshō yaku 開府儀同三司 特進試鴻臚卿肅國公食邑三千戸賜紫贈司空湓大鑑正 號大廣智大興善寺三藏沙門不空奉詔譯 (T 1135)

A második (T 1134A) és a harmadik (T 1134B) szövegnél csak „az állami szertartásokért felelös különlegesen elóléptetett megbízott vezető” 特進 (k. tejin $)^{80}$ 試鴻臚卿 (k. shi honglu qing) ${ }^{81}$ és a „,nagy igazságért érveló széles

79 Az angol nyelvú szakirodalmi múvek közül ki kell emelni Chou Yi-Liang 1945-ben írt Tantrism in China címú tanulmányát, amelyben a három fó mester életrajzával foglalkozik. Ennek rövidített összefoglalását adta magyar nyelven Hamar Imre Ezoterikus buddhizmus Kinában címú tanulmányában, amelyre például a titulusok fordításánál is hivatkozni fogok. Orlando Raffaello 1981-es PhD disszertációjában külön Amoghavajra életrajzait vizsgálja meg behatóan. A Tang-kori kínai rangok megfejtéséhez pedig Charles O. Hucker (1985) összefoglaló munkáját érdemes megemlíteni.

80 Hamar 2009: 76. A második a huszonkilenc tiszteleti cím közül. Hucker 1985: 490, 6335. bejegyzés.

81 Orlando 1981: 55. Az állami szertartásokért felelős minisztérium megbízott vezetője címet ugyanabban a császári parancsban adják neki, mint a fentebb említett tejint is. Hucker könyvében nem találjuk ezt a titulust. 
bölcsességü tripitaka (fordító) mester" 大辨正廣智三藏82 titulusok vannak megnevezve. Jóllehet a fordító neve nem szerepel, de a rangok alapján egyértelmúen Amoghavajrára ismerünk.

Az egyéb kinevezések nagy részét, pontosabban az ,erényekben páratlan parancsnok” 開府儀同三司 (k. kaifu yitong sansi) ${ }^{83}$ és a ,Su hercege 3000 háztartásos hübérbirtokkal” 肅國公食邑三千戸 kinevezéseket halálának évében, 774-ben kapta Taishū császártól, mint ahogy az a fennmaradt életrajzokban is szerepel.$^{84} \mathrm{Az}$ összes titulus azonban, amelyet életében és posztumusz szerzett, csak egy szövegnél látható, méghozzá a Fugen Enmei szútránál.

A fordító kiléte azon a ponton is megkérdőjeleződik, amikor a korábban említett nyolc szerzetes, illetve 9. századi japán templomok katalógusait megvizsgáljuk, amelyekben a szútrák megnevezése mellett sokszor a fordítót is megnevezik. Azt láthatjuk ezekben, hogy az issai szútránál többször is Vajrabodhi nevét adják meg mint fordítót. ${ }^{85}$

A második (T 1134A) és harmadik (T 1134B) szövegnél azonban a fordító kérdése helyett inkább az eredetiség kérdését kell megvizsgálni. Mivel ez a két szöveg csak a 19-20. században összeállított buddhista kánonokban jelenik meg, felvetődik az a probléma, hogy egyáltalán mikor, hol vagy hogyan keletkezhettek. A kínai buddhista apokrif irodalommal foglalkozó tanulmányok ${ }^{86}$ mind kiemelik, hogy az ezoterikus buddhizmusban is nagyon sok hibrid vagy hamisított szöveg lehet, amelynek hátterében az új kulturális környezethez való idomulás állhatott. A japán szövegeknél pedig olyan is előfordulhat, hogy esetleg már Japánban készültek. Ennek ellenőrzésére Sørensen öt kritériumot ad meg: 1) nem található meg egyetlen kínai buddhista katalógusban sem; 2) nincs benne a koreai tripițakában; 3) csak egy verzióban létezik; 4) nincs felsorolva a címe egyetlen olyan japán buddhista

\footnotetext{
Hamar 2009: 77.

Hucker 1985: 275.

Orlando 1981: 32.

55 Például Ennin már idézett Nittō shingu shōkyō mokurokujában is ez szerepel: 佛説一切如來 金岡川壽命陀羅尼經一卷 金岡潪譯 (T 2167, 55. köt. 1079c27).

86 Lásd Buswell 1990 vagy Sørensen (2011) tanulmánya.
} 
szerzetes katalógusában sem, aki Kínából tért haza; 5) csak valamilyen késői nyomatban maradt fenn.${ }^{87}$ Ezek alapján nézve a szövegeket, biztosan kijelenthetjük, hogy az issai szútra és a nenjuhō szöveg vagy indiai eredetú, vagy esetleg kínai hibrid szerzemény lehet. ${ }^{88}$ Mindehhez még azt is figyelembe kell vennünk, hogy a fordító sincs pontosan megnevezve. Mindez arra enged minket következtetni, hogy ez a szöveg talán nem kínai import - és valószínúleg a párja, a szertartási szöveg (T 1134A) sem az. Annyit bizonyosan tudunk, hogy a nenjuhō szöveghez kapcsolódnak, mivel az első dhāraṇīig írt rész szinte szóról szóra megegyezik. ${ }^{89}$ Azt nem lehet azonban megmondani a kutatás jelen állása alapján, hogy ezek a szövegek esetleg Japánban jöttek-e létre, vagy későbbi átvételek; esetleg egy ezoterikus buddhista szerzetes keze munkáját dicsérik, vagy szimplán a rövidítései és szertartásos kiegészítései az alapnak számító nenjuhō szövegnek.

Iyanaga Nobumi, majd Michel Strickmann is hasonló gyanút hangoztatott több szöveggel kapcsolatban, amelyeket hagyományosan Amoghavajrának tulajdonítanak..$^{90}$ Azt feltételezik ugyanis, hogy a szövegeket Amoghavajra (vagy egyik tanítványa) írhatta már Kínában. ${ }^{91}$ Ennek a kérdésnek az eldöntéséhez lehet, hogy Amoghavajra összes szövegének filológia vizsgálata sem lenne elég, ami természetesen túlmutat a jelen tanulmány keretein, úgyhogy most félretesszük a problémát, és egyelőre elfogadjuk, hogy a szövegeket Amoghavajra (vagy valamelyik tanítványa) fordította.

Sørensen 2011: 195.

88 A Fugen Enmei szútra az öt kitételből már csak egynek nem felel meg, ami nagyon kérdésessé teszi az indiai származást, és erősíti a kínai szerzőség lehetőségét. Erről bővebben egy későbbi tanulmányban fogok értekezni.

89 T 1133, 20. köt. 575a15-575b15; T 1134A, 20. köt. 576a11- 576b07; T 1134B, 20. köt. 577b19-577c15.

90 Iyanaga 1985: 642-643. n. 13. Iyanaga Osabe Kazuót 長部和雄 idézi, aki a Tang-kori buddhizmussal foglalkozó egyik alapmúvében (Osabe 1990: 126.) három részre osztotta fel Amoghavajra szövegeit aszerint, hogy fordítások lehetnek, vagy pedig - eredeti hiányában - esetleg az indiai szerzetes írásáról beszélhetünk-e. Michel Strickmann hozzáfúzése csak egy másik hivatkozásból érhetó el, mivel a Heralds of Maitreya címú tanulmánya nem került publikálásra, csak az 1983-as Princeton Conference on Maitreya Studies-on hangzott el, lásd Linrothe 1999: 192.n. 57.

91 Iyanaga 1985: 640-641. 


\section{Kulcsfontosságú motívumok a szövegekben}

A szútrákban a közös pont az élethosszabbítás motívuma. Ezen kívül hasonlóságok csak a két csoporton belüli szövegekben jelennek meg az igehirdetést végző buddha személyében, a résztvevőkben, a helyszínben, a gyakorlatok leírásában vagy a mantrák, dhāraṇ̄k szövegében. ${ }^{92}$

Mindegyik szútra egy igehirdetést mutat be, amelyben a helyszínek, az igehirdető személye és a résztvevők is különböznek a csoportoknak megfelelően. Ezek alapján az első csoportba sorolt három írásban Birushana buddha ${ }^{93}$ a Shumi-hegy 須弥山 (sz. Sumeru) tetején magyarázza el a gyémánt élethossz tanítását a buddháknak (j. nyorai 如来, sz. tathāgata), akiket később a kezükben gyémántot tartó bodhisattva (j. Shūkongō bosatsu 執金剛 菩薩, sz. Vajradhāra bodhisattva) csoporttal azonosít a szöveg.

A három szútrában megjelenik egy közös szereplő, a Gyémánt élethossz bodhisattva (j. Kongō jumyō bosatsu 金剛寿命菩薩), akinek kilétét nem fedi fel egyik szöveg sem. Két utalást találunk azonban, amiből kiderül a kapcsolat Fugen Enmei bosatsuval: az egyik a szertartást leíró T 1134A szöveg utolsó előtti sorában látható:

己浣。是普賢延命種子也 ${ }^{94}$



A másik utalást a Fugen Enmei szútrában olvashatjuk, ahol a tíz égtáj számos buddhájának (j. jippō chinsha shobutsu 十方塵沙諸佛) tudat-pecsétje

92 A szútrákban megjelenő meditációs vagy szertartási útmutatásokra, leírásokra egy későbbi, részletes vizsgálat során egy jövőbeni tanulmányban fogok kitérni.

93 A legelső (T 1133) szövegben Birushana hōjin butsuként 毘盧遮那報身佛 (Birushana jutalomtest buddha, sz. Saṃbhogakāya Vairocana) van feltüntetve. Ez a megnevezés az ezoterikus tanokban megjelenő három buddha-test (j. sanshin 三身, sz. trikāya) egyike, a jutalom-test. A nem ezoterikus tanokban Birushana a tan-test (j. hosshin 法身, sz. dharmakāya).

94 T 1134A, 20. köt. 577a26-577a27.

95 „Mag-mantra,” a legrövidebb, általában egy hangból álló mantrája egy-egy buddhista istenségnek. A mag az ālayavijñānára utal, ami magában hordozza minden jelenség lényegét. Az ezoterikus buddhizmusban ebben találhatók a különféle emberfeletti erők. (Soothill - Hodus 2004: 426.) 
által felruházott Fugen bosatsu 普賢菩薩 (sz. Samantabhadra) és a Négy mennyei király is elnyeri a gyémánt élethosszt, miután a Buddha után a fent említett buddhák is ezt a dhāraṇīt magyarázták.

説是陀羅尼已。大地山河悉皆振動。地獄摧碎宮震動。病 苦衆生當時蘇息。會中有無量執金剛神。異口同音亦共宣 説。諸大菩薩摩訶薩衆悉助延命宣説陀羅尼令獲金剛壽 命。爾時十方塵沙諸佛心印加持。令普賢菩薩及四天王増 得金剛壽命。96

Miután a dhāran̄īt elmondta, a föld, a hegyek, a folyók mind megremegtek és rázkódtak, a pokol összeomlott, a (mennyei) paloták megremegtek, és ugyanekkor az érző lények, akik betegek voltak és szenvedtek, mind meggyógyultak. Az összegyúltek között volt a számtalan vajradhara is, és ők is egyszerre mondták (ezt a dhāran̄īt), és a nagy bodhisattvák és mahāsattvák mind segédkeztek meghosszabbítani (az érző lények) életét, és elmondták a dhāraṇ̄t, és hagyták, hogy (az érző lények) megkapják a gyémánt élethosszt. Akkor a tíz irányban ${ }^{97}$ lévő világok tathāgatái, akik olyan sokan vannak, mint a homokszemek a Gangesz-folyóban, felhatalmazták Fugent és a Négy mennyei királyt saját tudat-pecsétjükkel, és elérték, hogy növekedjék (az életük), és megkapják a gyémánt élethosszt.

A második csoport szövegében az alap Buddha (j. butsu 佛) megszólítást használják, tehát Shaka buddha végzi az igehirdetést, méghozzá a Gangesz-folyó partján (j. Gōga 恒河, sz. Gañgā, a szövegben a 殑伽河 írásjegyekkel van jelölve). Nem a tathāgaták fogják hallgatni az igehirdetést, hanem a szerzetesek (j. bikusō 比丘僧, sz. bhikșu), a nagy bodhisattvák (j. daibosatsu 大菩薩, sz. mahābodhisattva) és az isteni lények (j.tennin 天人, sz. deva).

96 T 1136, 20. köt. 579b02-579b07.

97 A tíz irány: a négy fóégtáj, a négy mellékégtáj és a fel-le irányok. 
Az is különbség még a csoportok között, hogy az elsóben nem jelenik meg a Négy mennyei király, csak a második csoport két szövegében, ahol felesküdnek a Buddha előtt, hogy védelmezni fognak bárkit, aki az élethoszszabbítás dhāraṇīt recitálja és a megfelelő (korábban felsorolt) gyakorlatokat helyesen végzi.

我等四王即爲結護令無天横。如有此經清淨道場如不降 赴。願我失此威光損我果報。退失菩提心不得解脫 ${ }^{98}$ 。99

Mi, a Négy mennyei király, egybekötjük magunkat, és együttesen védelmezünk és biztosítjuk, hogy ne legyen idő előtti halál. Így, ha van ennek a szútrának egy tiszta oltára, és így, ha nem szállunk alá reá, fogadjuk, hogy elveszítjük fényünket, és elveszítjük áldásunkat, (így) visszafejlődünk a bodhicittánkból, és nem fogjuk elérni a felszabadulást.

Érdekesség, hogy Fugen bodhisattva csak az utolsó szövegben, a Fugen Enmei szútrában lép színre. A szövegek vizsgálatából ugyanis kitúnik egy olyan fejlődési folyamat, amely előkészíti az ő megjelenését, mintha a szövegekben felbukkanó motívumok a Fugen Enmei szútrában válnának teljessé. Itt természetesen nem az olyan talán elhanyagolható különbségekre gondolok, mint hogy hol zajlik a jelenet, vagy kik a szereplői, ugyanis ezek is fejlődtek az ezoterikus tanokkal együtt. Hanem a fóbb motívumokra, amelyek egyre inkább kibontakozni látszanak: a gyakorlatokra, a mantra vagy dhāraṇ̄ recitálásra, a Négy mennyei király megjelenésére stb. Eleinte a buddhák csoportjának szól a magyarázat, majd a szemlélők csoportja kibővül; először még nincs megnevezve konkrétan, hogy ki az a bodhisattva, akihez imádkozva elérhetik az élőlények a gyémánt élethosszt, aztán megtudjuk a kilétét. De említhetnénk a gyakorlatok fejlődésének avagy sokasodásának példáját is, amelyekkel elérhetjük a hosszú életet: először a recitálással, majd később

\footnotetext{
98 J. gedatsu (sz. vimokșa vagy vimukti) felszabadulás az eltévelyedésekből származó szenvedésekből, vagyis megvilágosodás.

99 T 1136, 20. köt. 579b27-579b29.
} 
már a szútra másolásával vagy Fugen Enmei képének rajzolásával is ugyanazt az eredményt kaphatjuk. Az első szövegben ezt olvashatjuk:

佛告執金剛菩薩。若有善男子善女人受持念誦日各三時時 別千遍。過去所有惡業因縁。短命天壽。由持此陀羅尼 故。信心淸淨業障銷滅。更増壽命。100

A Buddha azt mondta a vajradhara ${ }^{101}$ bodhisattváknak: „Ha vannak olyan jó férfiak és nők, akik megtartják és recitálják (ezt a dhāraṇīt) mindennap háromszor, és ezerszer minden alkalommal, akkor a múltbéli rossz karmában gyökerező rövid élet vagy korai halál (nem lesz), illetve megtartva ezt a dhāraṇīt, (a rossz karma) a hit által meg lesz tisztítva, (így) megsemmisülnek a karmikus akadályok, és ehhez még megnő az élethossz."

Az utolsóban, a Fugen Enmei szútrában pedig már az alábbiak szerepelnek:

爾時佛告四天王言。若有衆生怖畏死難病苦夭横。有如是 苦。但書寫此經受持讀誦。或別持此陀羅尼。或畫普賢延 命像。作此方法依月一日八日十五日。建立道場燒四十九 燈。花香果藥各置十六器散於壇上。合掌禮 拜高聲讃詠此 陀羅尼。及懺悔往各。不墮三惡道。捨此身獲得金剛壽命 更不輪迴。102

Akkor a Buddha azt mondta a Négy mennyei uralkodónak: „Ha vannak olyan érző lények, akik félik a halál nehézségét, a betegségtől való szenvedést, vagy a nem természetes (idő előtti) halált, és ha ilyen fajta szenvedéseik vannak, ha lemásolják ezt a szútrát, megtartják (tanításait) és recitálják, és ehhez még megtartják ezt a dhāraṇīt, vagy lerajzolják Fugen Enmei

100 T 1133, 20. köt. 575b17-575b20.

101 Jelentése: gyémántot tartó. Az ezoterikus buddhista bodhisattvákat jelöli, akik megkapták a tanok szimbólumának számító gyémántot (vajrát).

102 T 1136, 20. köt. 579c26-580a03. 
képmását, megtartják ezt a szertartást a hónap első, nyolcadik, tizenötödik napján, építenek egy $d \bar{o} j \bar{o} t,{ }^{103}$ (ahol) negyvenkilenc lámpást égetnek, és virágokat, füstölőket, gyümölcsöket és gyógyszereket helyeznek el, mindegyiket külön tizenhat tálkába, és szétszórják (ezeket) az oltáron, összeteszik a kezüket, imádatukat fejezik ki, hangosan dicsérik ezt a dhāraṇīt, és megbánják a múltbéli búneiket, akkor nem fognak a három rossz úton újjászületni. Ha megtagadják jelen testüket, akkor megkapják a gyémánt élethosszt, és nem fognak többé újjászületni."

Azt is láthatjuk a szövegek vizsgálatából, hogy változhatnak a jutalmak, avagy hasznok is, amelyek a gyakorlatokból erednek. Általában véve a végső cél az élethossz megnövelése, habár emellett még számos jótéteményt hozhat a szertartás (megfeleló) elvégzése. A szövegek első csoportjában a szertartást elvégzők

- életében nem lesznek katasztrófák, betegségek, viharok; ${ }^{104}$

- ország(uk) biztonságban lesz; ${ }^{105}$

- el fogják kerülni a korai halált (mivel a karmikus akadályok eltúnnek); ${ }^{106}$

- megkapják az öt természetfölötti erôt a levegóbe emelkedés szabadságával együtt ${ }^{107}$

- nem fognak szülók általi testben újjászületni. ${ }^{108}$

103 A dōjō 道場 megnevezés a szertartás helyét jelöli, általában ott készítették el az oltárokat a szertartáshoz. Eredetileg azt a helyet jelöli, ahol a Buddha megvilágosodott (Soothill - Hodus 2004: 416).

104 無諸災疫風雨。(T 1133, 20. köt. 576a01 és T 1134A, 20. köt. 577a16).

105 國土安泰。( T 1133, 20. köt. 576a01).

106 信心清淨業障銷滅。更増壽命。(T 1133, 20. köt. 576a01).

107 獲五神通。凌虚自在。( T 1133, 20. köt. 575b19-575b20).

108 不轉父母生身。(T 1133, 20. köt. 575b21, T 1134A, 20. köt. 576b13-14, T 1134B, 20. köt. $577 \mathrm{c} 21-577 \mathrm{c} 22)$. 
A második csoportba tartozó két szöveg (T 1135 és T 1136) szerint, akik rendesen betartják az előírásokat és elvégzik a szertartást, azok esetében

- növekedik az élethosszuk; ${ }^{109}$

- nem fognak betegségben szenvedni (akik abban szenvednek, azok azonnal meggyógyulnak), ${ }^{110}$

- nem fognak újjászületni a három rossz úton; ${ }^{111}$

- nem fognak félni a rövid élettől, a korai haláltól, a rossz álmoktól, az átok általi haláltól, a rakshasáktól, a démonoktól; ${ }^{112}$

- nem fog nekik ártani a víz, a túz, a fegyver vagy a méreg; ${ }^{113}$

- megvilágosodnak, és nem fognak visszafejlődni (a korábbi szintekre). ${ }^{114}$

Itt tehát már megjelenik egy komolyabb végcél, a legvégső bölcsesség elérése, a megvilágosodás.

\section{Gōzanze és Daijizaiten megjelenése a szövegekben}

Az első csoport három szútrája egy igen érdekes jelenettel kezdődik, nevezetesen arról olvashatunk, hogyan igázta le, majd térítette át a buddhista hitre Gōzanze 降三世 (sz. Trailokyavijaya) ${ }^{115}$ a Sumeru-hegy tetején található Akaniștha mennyország uralkodóját, Daijizaitent 大自在天 (másik nevén Makeishurát 摩櫭首羅, ami a szanszkrit Maheśvara japán hangi átirata).

109 増壽命。(Ez igazából minden szövegben elófordul többször is, például: T 1133, 20. köt. 575b13.)

110 病苦衆生。求長壽故離於病苦。(T 1136, 20. köt. 579b11).

111 不墮三惡道。( T 1135, 20. köt. 578c08).

112 無天死短命之怖。亦無惡夢魘魅呪。咀惡形羅刹鬼神之怖。(T 1135, 20. köt. 578c09).

113 不爲水火兵毒之所傷害。(T 1135, 20. köt. 578c10-11).

114 成就菩提到不退地。(T 1136, 20. köt. 579a14).

115 Jelentése a ,három világot legyőző." 
A három világ ${ }^{116}$ uraként $^{117}$ is tisztelt Maheśvara igazából nem más, mint Śiva, a hindu vallás egyik fó istensége. Ezek után már egyértelmúvé válik Gōzanze megnevezése is, mint a „három világot legyőző.” A három szövegben teljesen megegyezik a jelenet leírása:

毘盧遮那佛受諸如來請已。欲轉法輪時。即入三摩地。觀 見摩䤈首羅天等剛強難化。執著邪見。非我寂靜大悲之 身。堪任調伏。於時世尊入忿怒三摩地。從胸臆五峯金剛 菩提心。流出四面八臂威徳熾盛赫奕難酰降三世金剛菩薩 身。遍禮毘盧遮那及一切諸佛。唯願世悬示教於我。何所 爲作佛告降三世菩薩。汝今調伏難調諸天。令歸依諸佛法 僧發菩提心。諸天盡皆歸依。唯大自在天恃大威徳。來相 拒敵。降三世種種苦治。乃至於死。毘盧遮那佛入悲壂大 悲三昧耶。説金剛壽命陀羅尼。便入金剛壽命三摩地。乃 結印契加持摩醢首羅天。復還得蘇。更増壽命。歸依諸佛 灌頂。授記證得八地。118

Miután Birushana Buddha megkapta az összes buddha kérését, amikor meg akarta forgatni a dharma kerekét, abban a pillanatban belépett a samādhiba, ${ }^{119}$ ahol látta Makeishurát (sz. Maheśvara), a Nem-korlátozott Világ Lenyúgöző Istenségét, (aki) kimért volt, és nehéz volt megtéríteni, mivel a roszsz nézeteihez ragaszkodott. Az anātman ${ }^{120}$ nyugalma és a nagy könyörület tudta csak megtéríteni. Akkor, a Magasztos belépett

116 A három világ (j. sangai 三界, sz. tridhātu) felosztás a hindu és a buddhista kozmológiában is megjelenik, habár más-más világokat képviselnek. A buddhizmus ez a három a vágyak (j. yokukai 欲界, sz. kāmadhātu), a forma (j. shikikai 色界, sz. rūpadhātu), és a formanélküliség világa (j. mushikikai 無色界, sz. ārūpyadhātu), lásd Sawa 1975: 261.

117 A STTS szövegében nevezi meg saját magát Daijizaiten, mint a „hármas világ urát, az alkotót, a pusztítót, minden lény urát és az istenek istenét.” T 0882, 18. köt. 371a02-371a03. Fordítását lásd Chandra - Snellgrove 1981: 40 vagy Iyanaga 1985: 670. (A legyőzetésről bővebben lásd Chandra - Snellgrove 1981: 39-42, Iyanaga 1985: 633-745, Linrothe 1999: 183-188.)

118 T 1133, 20. köt. 575b01-14.

119 Magas fokú meditáció, az elme mély koncentrálása egy tárgyra. Jelentése: „összetenni”, „teljes elmélyedés”, ,,a meditáló és a meditált tárgy egyesülése” (Soothill - Hodus 2004: 67).

120 Japánul muga 無我 vagy higa 非我. Jelentése: nem-én, éntelenség. 
a könyörület és harag samādhiba, és mellkasából egy ötágú gyémánt bodhicitta ${ }^{121}$ jött elô, és Gōzanze 降三世 Gyémánt Bodhisattva négyfejú, nyolckarú teste, aki a fenséges erény és hatalom (lángjával) égett, amely rendkívüli, és amelyet nehéz látni, aki körben üdvözölte Birushana buddhát és az öszszes buddhát. „Kérlek, mondd meg, mit csináljak, és hogyan tegyek.” Így a Buddha azt mondta Gōzanzénak: „Te most megadásra készteted ezeket a nehezen tanítható istenségeket mind, és (készteted őket,) hogy menedéket találjanak a buddhákban, a dharmában és a szerzetesek közösségében, és (készteted ôket,) hogy a megvilágosodásra való vágy feltámadjon bennük." És ezzel abban a pillanatban mind megadták magukat. Az összes istenség, kivétel nélkül, menedéket talált a buddha, a dharma és a szerzetesi közösség (hármasában). Csak Makeishura volt, különlegesen nagyszerú és fenséges hatalommal (ellátva), aki ellenállást tanúsított. Gōzanze bodhisattva legyőzte (őt) nagy nehézségek árán, sőt még azt is elérte, hogy (Makeishura) meghaljon. Jobb lábával a Nagy istenségen, ${ }^{122}$ bal lábával az Istennőn ${ }^{123}$ taposott. ${ }^{124}$ Erre, miután Birushana Buddha belépett a nagy könyörületesség samādhiba, abban a pillanatban kimondta a gyémánt élethossz dhāraṇīt; továbbá belépett még a gyémánt élethossz samādhiba és a titkos kéztartást (sz. mudrā) formázta, és hatalmánál fogva újjáélesztette Makeishurát, és megkétszerezte az élethosszát, (aki pedig) menedéket talált a buddhákban, és felkelt benne a megvilágosodásra való vágy. (Birushanától) megkapta a beavatást (a titkos tanokba), ${ }^{125}$ és megvalósította a (bodhisattva) nyolcadik szintjét.

121 Megvilágosodás-tudat.

122 Makeishura hindu megfelelője Śiva.

123 Umahi, Makeishura hitvese, a hindu vallásban Śakti (egyéb neveken Umā, Pārvatī vagy Candikā).

124 Ez az egyik megjelenési formája Gōzanze Myōōnak 降三世明王 (sz. Trailokyavijaya-rāja).

125 Sz. Abhișeka, az ezoterikus titkos tanokba való beavatás szanszkrit megnevezése. 
Első ránézésre talán különösnek tünhet, hogy miért ezzel a jelenettel, ezekkel a szereplőkkel kezdődnek az élet-meghosszabbítás szövegek, de egy részletesebb vizsgálat rávilágít az összefüggésekre, ugyanis rögtön kiderül, hogy mindez csak egy rövid összefoglalója a korábban már érintett STTS szövegében található hosszabb jelenetnek. Ebben Birushana parancsára Kongōshu bosatsu 金剛手菩薩 (sz. Vajrapāṇi bodhisattva) legyőzi Daijizaitent. A Gyémánt-élethossz szövegben megjelenő Gōzanze bosatsu pedig nem más, mint Kongōshu bosatsu egyik (haragos) megjelenési formája. ${ }^{126}$ A bizonyosságot fokozza, hogy mindketten Birushana buddha mellkasából jönnek elő a szövegekben, vagyis Birushana egyetemes bölcsesség tudatának (j. fugenshin 普賢心) manifesztációi. Ez az egyetemes bölcsesség tudat pedig igazából nem más, mint Fugen bosatsu 普賢菩薩, aki később belép a hosszú élet samādhiba, és Fugen Enmei bosatsu lesz belőle. ${ }^{127}$ Ez a legfőbb motívum, ami egyértelmúen a STTS szöveg családjába helyezi a szútrá(ka)t, ahogyan ezt már Kūkai is látta a 9. század elején. ${ }^{128}$

Ez a legyőzés-legyőzetés motívum nem új keletű a buddhista szövegekben; a legelső példája, amikor Shakamuni, a történeti buddha legyőzi Marát 魔羅 (sz. Māra), a hindu démont. Mārat pedig Maheśvarával azonosítják, és mivel az említett szútrában (STTS) olvashatjuk, hogy miként lesz Shakamuniból Dainichi buddha 大日如来, ezért igazából teljesen ugyanaz a motívum játszódik le újra, csak immár ezoterikus szereplőkkel. ${ }^{129}$

126 Orzech 1998: 178.

127 T 1136, 20. köt. 579a10-579a17.

128 A teljesség igénye nélkül, azt azonban meg kell itt jegyezni, hogy a Kūkai által a 9. század elején ismert STTS nem a teljes fordítása volt a szövegnek, ugyanis arra a 10. század végéig kellett várnunk, amikor a Song Kínába érkezett Dānapāla elkészítette annak harmadik, egyben leghosszabb és legteljesebb verzióját (T 0882). Vagyis, bár a 8. században Vajrabodhi és Amoghavajra is készített fordítást ehhez a szútrához, Daijizaiten jelenete azokba nem került bele, ami arra enged minket következtetni, hogy teljesen más eredetiből dolgoztak, mint a fent említett buddhista szerzetes a 10. század végén. Így biztosnak látszik, hogy ez a jelenet legkorábban a Gyémánt-élethossz szövegekben túnt fel Kínában, majd Japánban is (ami a szöveg indiai származását is megerősítheti). De így felmerül a kérdés, hogy ha nem a legyőzetés jelenet alapján, akkor mégis mi alapján sorolta Kūkai ezeket a szövegeket ehhez a hagyományhoz? (Az STTS elemzéseihez bővebben lásd Chandra - Snellgrove 1981, Iyanaga 1985, Todaro 1985.)

129 Linrothe 1999: 178. 
A jelenetből egyértelmúen kitúnik, hogy a buddhizmus fényessége küzd a hinduizmus „hibás nézeteivel." ${ }^{130}$ A buddhizmust a szövegben Gōzanze (vagyis Birushana, aki nem más, mint Dainichi) testesíti meg, a hinduizmust pedig Daijizaiten és női társa, Umahi (sz. Ūmā). ${ }^{131}$ Itt a buddhizmusnak a hinduizmus felett aratott győzelme jelenik meg, annak ellenére, hogy a mahāyāna buddhizmus fejlôdése folyamán leginkább az ezoterikus panteonba került be jó néhány hindu istenség, akik általában a buddhizmust védelmező istenekként tűnnek fel.

\section{„Tiszta” vagy „zavaros” ezoterikus tanok?}

A japán tudósok körében kvázi tényként kezelik, hogy az ezoterikus tanokat vagy szútrákat (j. mikkyō 密教) két csoportba sorolhatjuk: a tiszta (j. jun 純) vagy a zavaros (j. zatsu 雑) tanokéba. Bár úgy látszik, hogy a nyugati kutatók nem támogatják a hasonló felosztást, a japán tudományos múvekben a mai napig megtalálható ez az elkülönítés. A tiszta ezoterikus tanokat (j. junmitsu 純密) Kiyota Minoru az 1970-es évek végén úgy definiálja, mint olyan ,tantrikus szövegek, amelyek a Mādhyamaka és Yogācāra iskolák filozófiai tantételeit” tartalmazzák, míg szerinte a zavaros tanok (j. zōmitsu 雑 密) szövegeiben megjelennek olyan népi hiedelmi elemek, mint a varázsigék, a jövendőmondás vagy a mágia. ${ }^{132}$ Kiyota idézi továbbá Matsunaga Yūkeit is, aki a hatvanas években a japán ezoterikus buddhizmus egyik kiemelkedő kutatója volt, leginkább annak történetével foglalkozott. Nála jelenik meg az a felfogás, hogy míg a zavaros ezoterikus szövegekben rendszerint Shaka buddha az igehirdető, addig a tiszta szövegekben már Vairocana tathāgata

$\overline{130}$ A szövegekben is megnevezik, ahogy olvashattuk, hogy az ellenálló istenségek hibás nézetekhez (j. jaken 邪見) ragaszkodtak.

131 Miután az STTS szövegben buddhista istenségekké váltak, ők is az ezoterikus panteont gazdagítják, ennek megfelelően megjelennek az Anyaméh-világ-mandala (j. Taizōkai mandara 胎蔵界曼荼羅, sz. Garbhadhātu mandala) 405 alakja között is, illetve több formában jelen vannak a japán ezoterikus múvészetben. Lokesh Chandra gyújtötte össze az alakjaikat 1977-es tanulmányában (lásd Lokesh 1977: 733-744).

132 Kiyota 1978: 6. 
a központi buddha. ${ }^{133}$ Matsunaga ezenkívül további feltételeket is szab a besoroláshoz, nevezetesen a mantra-, dhāraṇi- és mudrā-használathoz kötve. Szerinte ugyanis a korábbi zavaros szövegekben még nincs meg az a rendszer, ami a tiszta szövegekben a három titkon és a két fő mandalán keresztuil rendszerezi a tanokat. ${ }^{134}$

Abe 1999-ben szintén kitér a Nara-kori japán ezoterizmus tárgyalásánál a zōmitsu/junmitsu felállásra. Ő azonban elsődlegesen Ōmura Seigai 1918ban ${ }^{135}$ felsorakoztatott négy paraméterét idézi, amely szerint a tisztán ezoterikus tanokat fel lehet ismerni, ezek pedig a követezők:

1. a junmitsu szertartásban megjelenik a három misztikum (j. sanmitsu 三密) mindegyike, vagyis a mudrā, a mantra és a mandala előtti vizualizáció;

2. a junmitsu szertartás célja, hogy az élőlény életét megvilágosodottá tegye;

3. a junmitsu szövegeket dharma-testként azonosított Dainichi buddha hirdeti;

4. a junmitsu rendszer középpontjában a két világ mandala áll, ahogyan a Dainichi és STTS szövegben le vannak írva. ${ }^{136}$

133 Matsunaga 1969: 6.

134 Matsunaga 1969: 6: „The transition from Miscellaneous Esoteric Buddhism to Pure Esoteric Buddhism was a gradual one, and indeed it is difficult to separate clearly the division between the two, but the following consideration may be relevant here. Scriptures of the Miscellaneous Esoteric tradition generally take the form of sermons preached by the Buddha Sakyamuni, and concern magic and ceremonies designed to avert evil and bring about blessings. There is no unitary religious practice involving [mantra and] dharani, mudra [finger signs], or meditation, nor are the various Buddhas and bodhisattvas systematized into the scheme of a mandala [iconographic representation of truth]. The scriptures of the Pure Esoteric tradition are preached by Vairocana Tathagata; in the practice of the teachings set forth in these scriptures, meditation is combined with mudra and dharani (mantras), and the interrelationship between these three - which now have as their goal the attainment of the full illumination which is Buddhahood - is strongly stressed. Also a variety of mandalas are depicted in these Pure Esoteric Scriptures."

135 Ōmura 1918: 373-375.

136 Abe 1999: 152. 
Az előbb megjelölt kikötések, azaz a tiszta vagy zavaros kritériumai, csupán megfigyelésekből, a különböző szövegek összevetéséből következnek. Felmerülhet tehát bennünk a kérdés, hogy tekinthetjük-e ezeket mérvadó kritériumoknak? Ezekkel ugyanis egy olyan elfogadott normarendszert feltételeznénk, amelynek létét bizonyítani nem tudjuk, és a szóban forgó öt szöveg alapos vizsgálata is azt mutatja, hogy a határok a csoportok között igencsak homályosak. Az összes ezoterikus szöveg összevetése nélkül tehát nem állíthatunk fel konkrét hipotézist, ennek feladata pedig túlmutat egy kutató munkásságának megvalósítható keretein, a szövegek soksága, sokfélesége és értelmezésük nehézségei miatt.

Általános (a japán és a nyugati tudósok körében is), hogy az ezoterikus tanokban egy nagy váltást vélnek felfedezni a 8. században, egy határvonalat, amely elválasztja a korai és a késóbbi ezoterikus szövegek csoportját. A választóvonalat általában három - Kínában tevékenykedő - indiai pap nevével fémjelzik a szakirodalomban, nevezetesen Śubhakarasiṃha (j. Zenmui 善 無畏) és a már korábban is sokszor említett Vajrabodhi és Amoghavajra tevékenységével. Nekik köszönhetjük ugyanis a legfontosabb, az ezoterikus tanok alapszútráinak számító Mahāvairocana-szútra (j. Dainichi kyō 大日 経) és STTS szútrák, illetve még több száz ezoterikus szöveg kínai fordítását és ezzel Kelet-Ázsiában való elterjedésüket. Mivel a jelen tanulmányban tárgyalt négy szútrát is Amoghavajrának (avagy inkább Vajrabodhinak, lásd fentebb a fordító kérdését) köszönhetjük, a fordítás dátuma alapján a késői szövegek csoportjába kell sorolnunk ezeket.

A jelen szövegek esetében azt lehet megfigyelni, hogy az első csoport inkább a zavaros tanokhoz sorolható, míg a másik a tiszta tanokhoz. A fentebb tárgyalt motívumok alapján azonban nem lehet teljesen kizárólagosan besorolni őket egyik fajtába sem, ugyanis bár az első csoportban a gyakorlatok végzésének a célja úgynevezett világi eredmények, hasznok megszerzése, addig a központi buddha Birushana. Ugyanígy, a második csoportban már az eredmény is változik, ugyanis megjelenik a megvilágosodás eszméje, de az igehirdetô buddha valószínúleg Shakamuni, akit a zavaros ezoterikus szövegeknél látunk megjelenni. Ebből is levonhatjuk tehát a következtetést, 
miszerint az ezoterikus szövegek két részre osztása legalábbis nem minden esetben állja meg a helyét. Ugyanakkor azt is jelezheti ez nekünk, hogy ez a négy szöveg valahogy a két csoport határán keletkezhetett.

\section{Mantrák és dhāraṇīk}

A szövegekben van, ahol mantrákként, van ahol dhāraṇīkként hivatkoznak azokra a varázsigékre, amelyek sokszor a szútrák nevét is adják. A szövegek címében szereplő dhāraṇi szó azonban nem irányadó, ugyanis a fenti csoportosítást alátámasztva az elsó csoportban található összes szövegben a shingon 真言, vagyis igaz szavak (mantra), vagy a mitsugon 密言, vagyis titkos szavak megnevezés olvasható. Csak a második csoportban lévő szútránál (T 1135) jelenik meg egy hosszabb formátumú formula, amit már dhāraṇīnak nevez a szöveg.

Az első csoport szövegeiben megjelenik két alapvető jelentőségű mantra. $\mathrm{Az}$ összesben olvashatjuk a gyémánt élethossz mantráját (j. kongō jumyō shingon 金剛寿命真言), illetve a páncél mantráját (j. kacchū shingon 甲㫣 真言). Ezek mellett a sokkal inkább összetartozó, 1134 A és B szövegekben még olvashatunk egy négy írásjegyből álló mantrát is (j. shiji mitsugon 四字 密言), amelynek egy-egy karaktere a Gyémánt világ mạ̣ḍala (j. Kongōkai mandara 金剛界曼茶羅, sz. Vajradhātu maṇdala $)^{137}$ harminchét fó alakjának (j. sanjūnana son 三十七堊) ${ }^{138}$ egy csoportját képző négy kapuőrző bodhisattva (j. shishō bosatsu 四摂菩薩) ${ }^{139}$ egy-egy alakját jelképezi. ${ }^{140}$

137 Az ezoterikus buddhizmus két alapmandalájának, a Két világ mandalának (j. Ryōbu mandara 両部曼茶羅) egyike.

138 A harminchét főalak a következő: Dainichi buddha, a négy bölcsesség buddha (j. shichi nyorai 四智如来), a tizenhat főbodhisattva (j. jūroku daibosatsu 十六大菩薩), a nyolc felajánlás bodhisattva (j. hachikuyō bosatsu 八供養菩薩), a négy tökéletesség (sz. pāramitā) bodhisattva (j. shiharamitsu bosatsu 四波羅蜜菩薩) és a négy kapuórző bodhisattva.

139 A négy kapuőrző bodhisattva: Kongōkō bosatsu 金剛銁菩薩 (sz. Vajrāñkuśa, gyémánthorog); Kongōsaku bosatsu 金剛索菩薩 (sz. Vajrapāśa, gyémánthurok), Kongōsa bosatsu 金 剛鎖菩薩 (sz. Vajrasphoța, gyémántlánc) és Kongōrei Bosatsu 金剛鈴菩薩 (sz. Vajrāveśa, gyémántharang).

140 Ez a négy bodhisattva kapcsolódik Fugen Enmei alakjához is, ugyanis a húszkarú ábrázolásnál a tizenhat fó- és a négy kapuôrző bodhisattva attribútumai láthatók a húsz kézben (lásd Sawa 1970: 85-86). 
A szövegek csoportjain belül az egyetlen eltérés a siddham szanszkrit karakterek használatában vagy éppen elhagyásában látható. Míg az első szövegben csak a hangi átírásos mantrák vannak feljegyezve, addig a másik két szútrában szanszkrit karakterekkel is megjelennek a kínai karakterek mellett.

A mantrák a szövegekben a következők: ${ }^{141}$

1. Gyémánt élethossz mantra 金剛寿命真言

唵＼cjkstart嚩日囉二合 喻矖 娑㗘 二合引 賀引

唵 嚩日羅二合 喻灑 娑㗘二合 賀

唵 嚩日囉二合喻㲋 薩㗘二合 訶引

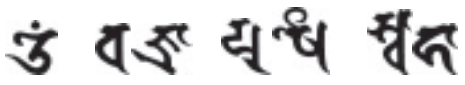

Om vajrāyuṣe svāhā

\section{Páncél mantra 甲曺真言}

唵 砧 讁䙃反 㗘日囉二合 欲

唵引一 碪 謫籫切二 㗘日囉二合 欲三

唵 砧讁䙃反㗘日囉二合欲

\section{के वर्व}

Om ddhām vajrāyuh

3. Négy írásjegy mantra 四字密言

弱 吽 鋑 斛

惹 吽 鋑 斛

\section{ス゚ங் ๘்}

jaḥ hüm vam hoh

A mantrákkal és dhāraṇīkkal kapcsolatos szakirodalmi múvek erősen hangsúlyozzák, hogy a formulák lefordítása nemcsak mellékes, de szinte lehetetlen is. Ez a kínai hangi átírásokra azonban többszörösen is érvényes, mert

141 A mantrák sorban a T 1133, T 1134A és T 1134B szövegek szerint vannak, utána pedig a siddham szanszkrit betúk következnek, amelyek a két utóbbi szútrában teljesen megegyeznek. Az utolsó sorban a siddham latin betûs átírása olvasható. 
mint a fentiekből láthatjuk, ugyanarra a szóra, kifejezésre többféle írásjegyet is használtak (bár olvasatuk sokszor nem változik). Ez hagyományozódott tovább Japánban is, amikor a Kínában tanuló japán buddhista szerzetesek a szanszkrit tanulmányokat hazavitték magukkal. ${ }^{142}$

A fordítás ellen szól az a tény is, hogy a hangok gyakorta nem tesznek ki értelmes szavakat. ${ }^{143}$ Természetesen ettől még vannak értelmes szavak is a mantrákban. A fenti mantrák közül például az elsőnek az általános kezdő (oṃ) és végkifejezések ( $s v \bar{a} h \bar{a})$ mellett két értelmes szava is van, a vajrāyuṣe, ami a gyémánt élethosszt jelenti. ${ }^{144}$ A gyémánt élethossz mantra azonban nem csak itt jelenik meg. A British Múzeumban található, Hidas Gergely tanulmányában feldolgozott egyik talizmánon Om vajrāyoṣe svāhā feliratként olvasható ugyanez a mantra. ${ }^{145} \mathrm{~A}$ talizmán a dunhuangi 17-es (könyvtár) barlangból került elő, és Sir Aurél Stein által került a londoni múzeum gyújteményébe. ${ }^{146}$ A talizmánon Amida buddha 阿弥陀仏 (sz. Amitābha) alakja látható, a szanszkrit feliratok (főleg dhāraṇ̄̄k) is hozzá kapcsolódnak. Az élethossz dhāraṇī megjelenése nem teljesen meglepő, hiszen Amida neve szanszkritul lehet Amitábha, aminek jelentése ,végtelen fény," illetve Amitāyus, avagy „végtelen élet.”

A második csoportba tartozó szövegben a mantrák már dhāraṇ̄k lesznek, megnevezéseik is változnak. Gyémánt élethossz dhāraṇī néven egy sokkal hosszabb szöveg olvasható, aminek a végén jelenik meg a fent említett, az első csoport írásaiban található rövid mantra a Fugen Enmei szútrában, ugyanis az 1135-ös szövegben még ez is eltér. Emellett van egy Hosszú élet dhāraṇi (j. enmei darani 延命陀羅尼) mind a két szövegben, illetve ez a Négy mennyei király négy verziójaként előadva. A Fugen Enmei szútrában a Négy mennyei király

142 Fennmaradt például Kūkainak, a shingon irányzat japán meghonosítójának a siddham karakterekról írott, a korabeli szanszkrit tanulmányok egyik alapmúvének számító, a Siddham anya-karakterek [mātrkā] a jelentésük magyarázatával 梵字悉量字母并釋義 címú múve. (T 2701, 84. köt. 361-364.)

143 Friedrich Max Müller 1884-ben megjelent tanulmányától (Uṣṇ̄sṣavijayā dhāraṇī) kezdve, egészen a közelmúltban kiadott, Harvey Alper által szerkesztett Understanding Mantras címú könyvig még mindig vitatják a kutatók, hogy egyáltalán érdemes-e a mantrák és dhāran̄īk fordítását erőltetni.

144 A gyémánt élethosszt vajrāyusként találjuk meg Hirakawa (1997: 1185) kínai-szanszkrit nagyszótárában.

145 Hidas 2014: 110.

146 Hidas 2014: 110. 
dhāraṇīja közül az egyik a korai halál elkerülésére van (j. kaji gonen johimyō darani 加持護念除非命), a többi pedig a hosszú élet elérésére. Egyik szövegben sincs siddham szanszkrit a kínai karakterek mellett. A dhāraṇ̄k megfejtése mindezek után lehetetlenség lenne, ha az egyik tendai szerzetes a szútrákhoz és azok szertartásaihoz füzött kommentárjában nem jegyezné fel hozzájuk a siddham karaktereket is. ${ }^{147}$ Ez a kommentár azonban négyszáz évvel később készült, mint maguk a szútrafordítások. Sajnos nem derül ki, hogy melyik szövegben találta meg a siddham karaktereket az író, de utána megad háromféle átiratot három különböző fordító nevével: az egyik Vajrabodhi, a másik Devaprajñā, a harmadik pedig Amoghavajra.

\section{Összefoglalás}

Az Amoghavajrának tulajdonított szövegek, amelyeknek a központi témája az élethosszabbítás, az ezoterikus szövegek minden jellegzetességével rendelkeznek: főszereplőik az ezoterikus panteon alakjai, vannak bennük varázsige jellegú formulák (mantrák, dhāraṇīk), és céljaik között a világiak (az első három Gyémánt-élethossz szöveg) mellett már feltúnik a spirituális végső megszabadulás (a második csoportba sorolható két szöveg esetében) is. Így olyan változást figyelhetünk meg, amely egyfajta fejlódést mutat a világitól a spirituális felé, de alapvetően a bodhisattva-ideált erősítve, az érző lények vágyainak beteljesítése általi megmentésük marad a fó motívum az összes szútrában. Jelen szövegek vizsgálata hozzájárulhat a japán buddhista kultúrtörténet mélyebb megismeréséhez is, mivel a szútrákhoz tartozó, a császárok beavatási ceremóniájának alkalmával, a császári utódok születéseinél vagy a magas rangú emberek betegségeinél elvégzett Enmeihō, Fugen Enmeihō szertatások a Heian- és Kamakura-kori császári udvarban, a császári család körében, az arisztokrata osztályban, sôt még a shōgunok között is igen nagy népszerúségre tettek szert. A Fugen Enmeihō a tendai irányzatban egyike lett a négy nagy szertartásnak (j. shika daihō 四箇大 法), amelyeket a mai napig minden év áprilisában megtartanak.

147 Gyōrinshō 行林抄, összeállította Jōnen 静然 (?-?, a Heian-kor második felében élt tendai szerzetes), T 2409, Vol.76. Az egész 17. tekercs az élethosszabbítás szertartásával foglalkozik. 


\section{Elsődleges források}

\section{Szútrák}

Bussetsu issai nyorai kongō jumyō darani kyō 仏説一切如来金剛寿命陀 羅尼経 (A Buddha által hirdetett, minden buddha Vajra-élethossz dhāraṇi szútrája), T 1135, 20. köt.

Kongō jumyō darani nenjuhō 金剛寿命陀羅尼念誦法 (A gyémánt-élethossz dhāraṇ̄ megfelelő recitálásának szertartása), T 1133, 20. köt.

Kongō jumyō darani kyō 金剛寿命陀羅尼経 (A gyémánt-élethossz dhāraṇ̄ szútra), T 1134B, 20. köt.

Kongō jumyō darani kyōhō 金剛寿命陀羅尼経法 (A gyémánt-élethossz dhāraṇi szútra szertartása), T 1134A, 20. köt.

Shobutsu jūe darani kyō 諸仏集会陀羅尼経 (A tathāgaták gyúlésének dhāraṇī szútrája), T 1346, 21. köt.

\section{Buddhista katalógusok}

Daitō teigen zoku kaigen shakkyō roku 大唐貞元続開元釈教録 (A Tang-korban a Kaigen időszak folytatásaként a Teigen időszak tanmagyarázatainak katalógusa), T 2156, 55. köt.

Go-shōrai mokuroku 御請来目録 (Az újonnan behozott [tanok] katalógusa), T 2161, 55. köt.

Nihon biku Enchin nittō guhō mokuroku 日本比丘圓珍入唐求法目録 (A Tang Kínában a japán bhikṣu, Enchin által szerzett tanok katalógusa), T 2172, 55. köt.

Nittō shing ū shōkyō mokuroku入唐新求聖教目錄 (A Tang Kínában újonnan szerzett szent tanok katalógusa), T 2176, 55. köt. 
Seiryūji guhō mokuroku 青龍寺求法目録 (A Seiryūji templomban szerzett tanok katalógusa), Taishō shinshū daizōkyō T 2171, 55. köt.

Shingonshū shogaku kyō-ritsu-ron mokuroku 真言宗所学経律論目録 (A shingon irányzat tanainak, a szútráknak, a vinayáknak és adhidharmáknak a katalógusa) (http://base1.nijl.ac.jp/iview/Frame.jsp?DB_ $\mathrm{ID}=\mathrm{G} 0003917 \mathrm{KTM} \& \mathrm{C} \_$CODE$=$XSE1-00103)

Sho ajari shingon mikkyō burui sōroku 諸阿闍梨真言密教部類綜録 (Számos ācārya shingon ezoterikus tanának összesített katalógusa), T 2171, 55. köt.

Shoku nihongi 続日本紀, Kokushi taikei 国史大系 2, 1897 (http://dl.ndl. go.jp/info:ndljp/pid/991092)

Taishū chō zōshi kū daibenshō kōchi sanzō wajō hyōsei shū 代宗朝贈司空 大辯正廣智三藏和上表制集 (), T 2120, 52. köt.

Teigen shintei shakkyō mokuroku 貞元新定釈教目録 (A Teigen időszakban újonnan szerzett tanmagyarázatok katalógusa), T 2157, 55. köt.

\section{Internetes adatbázisok}

(A Tokió Egyetem történeti forrásokkal foglalkozó kutatóintézetének interneten is elérhető anyaga: http://www.hi.u-tokyo.ac.jp/index-j.html)

Dai nihon shiryo sōgō dētabēsu 大日本史料総合データベース (A japán történeti források nagy összefogó adatbázisa)

Nara jidai komonjo furu tekisuto dētabēsu 奈良時代古文書フルテキスト データベース (A Nara-kori régi iratok teljes szöveges adatbázisa)

Nihon komonjo yunion katarogu dētabēsu 日本古文書ユニオンカタログ データベース (A régi japán iratok egységes katalógus adatbázisa) 


\section{Forrásgyújtemények}

Bussho Kankōkai 仏書刊行会 (ed.) 1917-1918. Chishō daishi zenshū 智証大 師全集 [Chishō daishi összes múve]. 4. köt. Tokió: Bussho kankō kai.

Kōbō Daishi Kūkai Zenshū Henshū Iinkai 弘法大師空海全集編集委員会 (ed.) 1984. Kōbō Daishi Kūkai zenshū 弘法大師空海全集 [Kōbō Daishi Kūkai összegyújtött munkái]. Tokió: Chikuma Shobō.

Takakusu Junjirō 高楠順次郎 (eds.) 1989. Taishō shinshū daizōkyō 大正新 脩大蔵経 [Taishō időszakbeli újonnan összeállított kínai Tripitaka], Tokió: Taishō shinshū daizōkyō kankōkai.

\section{Felhasznált másodlagos szakirodalom}

Abe Ryūichi 1977. The Weaving of Mantra: Kükai and the Construction of Esoteric Buddhist Discourse. New York: Columbia University Press.

Chou, Yi-liang 1945. „Tantrism in China.” Harvard Journal of Asiatic Studies, 3/4: 241-332.

Hamar Imre 2009. „Az ezoterikus buddhizmus története Kínában.” In: Hamar Imre - Salát Gergely (szerk.) Kinai történelem és kultúratanulmányok Ecsedy Ildikó emlékére, Sinológiai Múhely 7. Budapest: Balassi Kiadó, 65-79.

Hatsuzaki Shōjun 初崎正純 1966. „Enmeihō ni kan suru bukkyō kyōten no kenkyū 延命法に関する仏教経典の研究 [Az élethosszabbítási szertartással kapcsolatos buddhista szútrák kutatása]." Indogaku bukkyōgaku kenkyū 印度学仏教学研究 15.1: 225-229.

Hatsuzaki Shōjun 初崎正純 1968. „A Study of the Dhâraṇi in the Jani-tam.” Indogaku bukkyōgaku kenkyū 印度学仏教学研究 16.2: 937-942. 
Hidas Gergely 2014. „Two dhāraṇi prints in the Stein Collection at the British Museum." Bulletin of the School of Oriental and African Studies 77.1: 105-117.

Hidas Gergely 2015. „Dhāraṇ̄ Sūtras.” In: J. Silk - O. von Hinüber - V. Eltschinger (eds.) Brill's Encyclopedia of Buddhism. Vol. I. Literature and Languages. Leiden: Brill, 129-137.

Hirakawa, Akira 1997. Buddhist Chinese-Sanskrit Dictionary 仏教漢梵大 辞典. Tokyo: Reiyukai.

Hucker, Charles O. 1985. A Dictionary of Official Titles in Imperial China. Taipei: Southern Materials Center Inc.

Iyanaga, Nobumi 1985. „Récits de la soumission de Maheśvara par Trailokyavijaya, d'après les sources chinoises et japonaises.” In: Michel Strickmann (ed.) Tantric and Taoist Studies in honour of R. A. Stein. 3. köt, Mélanges Chinois et Bouddhiques, XXII. Bruxelles: Institut Belge des Hautes Études Chinoises, 633-745.

Jiang, Wu - Chia, Lucille 2015. Spreading Buddha's Word in East Asia: The Formation and Transformation of the Chinese Buddhist Canon. New York: Columbia University Press.

Kiss Mónika 2014. „Fugen Enmei bosatsu ikonográfiai meghatározásának néhány problematikus pontja." Távol-keleti Tanulmányok 2014/1-2: 67-92.

Kiyota, Minoru 1978. Shingon Buddhism: Theory and Practice. Los Angeles/Tokyo: Buddhist Books International.

Linrothe, Rob 1999. Ruthless Compassion: Wrathful Deities in Early Indo-Tibetan Esoteric Buddhist Art. Boston: Shambhala Publications.

Lokesh Chandra 1977-1978. „The Iconography of Umā and Maheśvara in Japanese Art." Annals of the Bhandarkar Oriental Research Institute 58/59: 733-744. 
Lokesh Chandra - Snellgove, David L. 1981. Sarva-tathāgata-tattva-saìgraha: Facsimile Reproduction of a Tenth Century Sanskrit Manuscript from Nepal. New Delhi: Jayyed Press

Maki Nobuyuki 牧伸行 1994. „Tōdaiji sō Angan to Heiei 東大寺僧安寛 と平栄 [Angan és Heiei, a Tōdaiji templom szerzetesei].” Bukkyō daigaku daigakuin kiyō 佛教大學大學院紀要 22: 22-47.

Matsunaga Yūkei 1969. „Tantric Buddhism and Shingon Buddhism.” The Eastern Buddhist (New Series) 2.2: 1-14.

Nanjō Bunyū 1883. A Catalogue of the Chinese Translation of the Buddhist Tripitaka: The Sacred Canon of the Buddhists in China and Japan. Oxford: Clarendon Press.

Ōmura Seigai 1918. Mikkyō hattatsushi 密教発達史 [Az ezoterikus tanok fejlődésének története]. Tokió: Kokusho kankōkai.

Orlando, Raffaello 1981. A Study of Chinese Documents Concerning the Life of the Tantric Buddhist Patriarch Amoghavajra (A.D. 705-774). PhD disszertáció. Princeton University.

Orzech, Charles D. 1998. Politics and Transcendent Wisdom: The Scripture for Humane Kings in the Creation of Chinese Buddhism. University Park, Pennsylvania: Pennsylvania State University Press.

Osabe, Kazuo 長部和雄 1990. Tōdai mikkyō shi zakkō 唐代密教史雑考 [Különféle gondolatok a Tang-kori ezoterikus buddhizmus történetéről]. Tokió: Hokushindō.

Reischauer, Edwin O. 1955a. Ennin's Travels in T'ang China. New York: The Ronald Press Company.

Reischauer, Edwin O. 1955b. Ennin's Diary. New York: The Ronald Press Company. 
Sawa Ryūken 佐和隆研 1970. Butsuzō zuten 仏像図典 [Buddhista szobrok ábrázolásainak enciklopédiája]. Tokió: Yoshikawa Kōbunkan.

Soothill, William E. - Hodous, Lewis (eds.) 2004. A Dictionary of Chinese Buddhist Terms with Sanskrit and English Equivalents and a Sanskrit-Pali Index. New York/London: Routledge.

Sørensen, Henrik H. 2011. „The Apocrypha and Esoteric Buddhism in China." Charles D. Orzech - Henrik H. Sørensen - Richard K. Payne (eds.) Esoteric Buddhism and the Tantras in East Asia. Leiden: Brill,181-196.

Takami Kankyō 高見 寛恭 1978. „Nittō hakka no mikkyō sōshō ni tsuite (1) 入唐八家の密教相承について (一).” Mikkyō bunka 密教文化 122: $1-8$.

Takami Kankyō 高見 寛恭 1979. „Nittō hakka no mikkyō sōshō ni tsuite (2) 入唐八家の密教相承について (二). ” Mikkyō bunka 密教文化 126: $1-16$.

Takami Kankyō 高見 寛恭 1980. „Nittō hakka no mikkyō sōshō ni tsuite (3) 入唐八家の密教相承について (三).” Mikkyō bunka 密教文化 130: $26-41$.

Todaro, Dale Allen 1985. An Annotated Translation of the Tattvasamgraha (Part 1) with an Explanation of the Role of the Tattavasamgraha Lineage of Kūkai. Phd disszertáció, Columbia University. 